\title{
Ultimate attainment in heritage language speakers: Syntactic and morphological knowledge of Italian accusative clitics
}

\author{
Francesco Bryan Romano (i) \\ Stockholm University \\ Corresponding author. Email: francesco.romano@miun.se
}

(Received 02 February 2019; revised 03 November 2019; accepted 18 November 2019)

\begin{abstract}
The acquisition of a heritage language, normally the weaker language of early bilinguals, has been oftentimes defined as incomplete, especially for morphosyntax. As a result, these early bilinguals resemble late bilinguals more than native language speakers, calling into question the role of age of exposure. The effects of syntactic complexity on knowledge of morphosyntactic structures, however, have not been sufficiently considered hitherto. This study investigates age of exposure and syntactic complexity by comparing heritage, second language, and native language speakers on knowledge of Italian accusative clitics in three structures. An oral structural priming task and a speeded grammaticality judgment task find a discrepancy in the level of ultimate attainment heritage speakers reach for syntax and morphology. While their abstract representation of clitic structures approximates that of native language speakers more closely, their morphological knowledge of clitics aligns with second language speakers, suggesting early exposure has tangible effects only on syntactic knowledge. In turn, syntactic complexity affects the representation of clitic structures in a predictable manner, but is inconsequential to explicit knowledge of morphological forms in monolingual and bilingual speakers. Lack of age of exposure effects in the morphological domain are attributed to interface vulnerability.
\end{abstract}

Keywords: age of exposure; clitics; heritage languages; priming syntactic complexity

Heritage language speakers (HLers) are early bilingual speakers of a stronger, usually dominant, language and a weaker, minority family language. Despite very similar scheduling of first exposure to the native family language as monolinguals, these speakers attain incomplete linguistic systems, which has been the subject of controversy (Kupisch \& Rothman, 2016; Montrul, 2008, 2009, 2016; Polinsky, 2018; Putnam \& Sanchez, 2013). One area in which heritage and native language (L1) speakers have been notoriously found to differ is morphosyntax, especially in the acquisition of Spanish as the weaker language (Carreira \& Kagan, 2018; Montrul \& Bowles, 2009; Montrul, Foote, \& Perpiñán, 2008a, 2008b; Montrul \&

(C) Cambridge University Press 2020. This is an Open Access article, distributed under the terms of the Creative Commons Attribution-NonCommercial-NoDerivatives licence (http://creativecommons.org/licenses/by-nc-nd/4.0/), which permits non-commercial re-use, distribution, and reproduction in any medium, provided the original work is unaltered and is properly cited. The written permission of Cambridge University Press must be obtained for commercial re-use or in order to create a derivative work. 
Perpiñán, 2011; Silva-Corvalán, 1994, 2014). It has been observed that on a par with late bilingual speakers (L2ers), HLers differ from L1 speakers in use of gendermarking forms (Montrul, 2010a; Montrul et al., 2008a). This morphological divergence between bilingual and more monolingual populations stands opposite evidence that heritage and L1 speakers resemble one another for knowledge of more syntactic properties like wh-extraction and that-trace violations (Montrul et al., 2008b) and Swedish V2 (Håkansson, 1995). The syntax-morphology discrepancy in the acquisition of heritage languages casts doubt on the role of age of exposure and its benefit to language acquisition in general. Research to date, however, has focused for the most part on Spanish. In a state-of-the-art of current research in HL acquisition with application to language pedagogy, Carreira and Kagan (2018, p. 156) call for expansion of research to lesser known HLs, a call that is tackled head on by the present study. I address the role of age of exposure by adducing novel evidence from Italian, a heavily understudied language in both L2 and HL research. The evidence yielded for a language such as Italian, which shows considerable overlap with Spanish on a number of morphosyntactic properties-including but not limited to gender-marking forms - due their typological similarity, is unique and sheds light on the cross-linguistic plausibility of the findings for Spanish.

Another factor explaining divergence between L1 and bilingual knowledge of morphosyntactic properties is the syntactic complexity of structures in which such properties are used (Montrul, 2010a). L2ers of Italian are known to develop L1-like knowledge of the placement properties of accusative clitics earlier than their morphological form (Santoro, 2007), showing an interesting parallel to HLers. A second goal of this study is, thus, to explore the role of syntactic complexity in the ultimate attainment of morphosyntax by HL and L2ers.

\section{Heritage language acquisition and age of exposure}

HLers are early simultaneous or sequential bilinguals raised under exposure to a stronger, environment language, and a weaker, family language. Theoretically, HLers are native speakers of the family language much like their monolingual counterparts in that exposure to the language starts from birth. ${ }^{1}$ However, early bilinguals' weaker language development and ultimate attainment varies considerably depending on amount of exposure, cross-linguistic influence, age of onset, language dominance, proficiency, and attrition (Carreira \& Kagan, 2018; Flores, Kupisch, \& Rinke, 2019; Kanno, Hasegawa, Ikeda, Ito, \& Long, 2008; KondoBrown, 2006; Montrul, 2016). Flores et al. (2019), for instance, stress the relevance of language dominance as a defining feature of heritage speaker competence. The dominant language is all too often the language for which HLers possesses better accuracy and fluency, production and processing, as well as faster parsing speed and wider lexical array (p. 624). Similarly, the end state grammar of HLers is determined by the delicate interplay of the quality and quantity of input received. The children of immigrant families may be exposed to a variety of the heritage language spoken by the parents that differs in substantial ways from the standard variety. Such deviance is crucial given that nativeness and generalizations about target-like linguistic knowledge are normally based upon the standard. The input received at home may be proper of a language that has been passed down from 
generation to generation, that has attrited, eroded, and lost features of the standard norm over time (but see Montrul, Bhatt, \& Girju, 2015, that this is not always the case). This may, in turn, lead to an end state grammar that is non-target-like.

The outcome of heritage and L1 acquisition differ in meaningful ways. While typically developing children attain complete and uniform knowledge of their native language and show far less variability in terms of grammatical intuitions by the time the adult grammar has matured, children raised in the heritage language do not (Montrul, 2009). They are often characterized by variation in success, course, and strategy, fossilized grammars, and display indeterminate intuitions (Håkansson, 1995; Montrul et al., 2008a, 2008b). In other words, despite very early exposure, heritage languages do not develop target-like systems in some domains, which remain incompletely acquired, reflecting instead striking similarities to L2s (Montrul, 2008, 2016). Incomplete acquisition of a heritage language is well documented with respect to grammatical case, some features of verbal morphology, and flexible word order (Carreira \& Kagan, 2018).

Age of first exposure is presumed to effect differences in ultimate attainment between HLers and late bilinguals (i.e., L2ers). Whereas HLers are exposed to the weaker language early on in life, primarily in naturalistic settings where most of the input is oral, the latter usually learn the L2 formally in instructed settings via both written and oral input. Under the purview of scholars who assume a deterministic role of the critical period for L2 attainment (Bley-Vroman, 1990; Clahsen \& Muysken, 1986; DeKeyser, 2000, 2003; Hawkins \& Chan, 1997; Hyltenstam \& Abrahamsson, 2003), these differences in quality and age of exposure are expected to lead end state HL grammars to converge on L1 grammars. To the extent that age of exposure has permanent effects on ultimate attainment in L2ers (Bley-Vroman, 1990; Clahsen \& Muysken, 1986; DeKeyser, 2000, 2003; Hawkins \& Chan, 1997; Hyltenstam \& Abrahamsson, 2003; Long, 1990; Meisel, 1997; Paradis, 2004; Schachter, 1990; Smith \& Tsimpli, 1995), HLers are comparatively predicted to develop more L1-like competence.

Evidence that early exposure leads to more monolingual-like competence, however, is limited both in quantity and in methodology. On the one hand, early exposure has been found to have little impact on the acquisition of the more morphological aspects (i.e., form realization) of properties like gender (Montrul et al., 2008a, 2008b; Polinsky, 2008a, 2008b), mood morphology (Montrul \& Perpiñán, 2011; Potowski, Jegerski, \& Morgan-Short, 2009; Silva-Corvalán, 1994, 2014), and differential object marking (Montrul \& Bowles, 2009), but there are clear and consistent advantages for phonology. In the area of syntax, however, some studies show advantages in languages such as Spanish (Montrul, 2010a, 2010b), Korean (Chung, 2018), and Swedish (Håkansson, 1995). In consequence, Montrul (2010a) asks whether the lack of age of exposure effects on the acquisition of morphological competence may be tied to the specific structures in which forms surface (p. 169), suggesting that research pursue the study of specific grammatical properties in greater depth, analyzing their linguistic complexity and the manner in which they are used within different structures. In this study, the above are tackled head-on by examining the oral production of Italian accusative clitics in three distinct constructions. 


\section{Contrasting heritage, second, and first language knowledge of morphosyntax}

Four core studies have contrasted knowledge of morphosyntactic properties in heritage, L2, and L1 speakers, Montrul et al. (2008a), Montrul (2010a, 2010b), Polinsky (2008a), and Håkansson (1995). Montrul et al. (2008a) investigated gender marking in L2 Spanish comparing L2 learners and HLers with L1 English ranging from low to advanced proficiency level with native Spanish speakers. The L2 learners started acquiring Spanish at or soon after puberty and received input in both instructed and naturalistic settings. In contrast, the HLers were exposed to and used Spanish from birth. Both groups were schooled in English, which constituted the dominant

language. The three tasks employed, a written picture identification, a written elicited production, and an oral picture description, tested agreement for gender and number. Spanish marks gender on determiners, nouns, and adjectives, as shown in examples (1) and (2).

(1) $\mathrm{La}$ the.DET.FEM "the red house"

(2) El the.DET.MASC "the red car"

$$
\begin{array}{ll}
\text { casa } & \text { roj-a } \\
\text { house.N (FEM) } & \text { red.ADJ-FEM }
\end{array}
$$

auto roj-o

car.N (MASC) red.ADJ-MASC

While gender marking on nouns is intrinsically lexical, denoted by the parenthesized attribute for gender (FEM)/(MASC) in the examples, determiners and adjectives encode a syntactic gender feature FEM/MASC, which they inherit via agreement with the noun. It was found that the L2 and the HLers at lower and intermediate proficiency levels made significantly more errors than the L1 speakers. Thus, in spite of exposure to Spanish from birth in a manner comparable to the L1 group, most HLers performed more like postpubertal L2 learners. Moreover, errors in the heritage and L2 groups were in line with previous studies of L2 Spanish (Bruhn de Garavito \& White, 2002; McCarthy, 2007), manifestly in relation to the overgeneralization of masculine gender to feminine words (e.g., la casa roj-o). The advantages tied to effects of age of exposure, therefore, did not bear out in the data.

Another core study conducted by Montrul (2010a) compared L1 speakers to low-intermediate L2 and heritage speakers with L1 English on knowledge of a number of properties tied to Spanish accusative and dative clitics. Results from an oral production task show that HLers and L1 speakers produce more similar amounts of clitics than L2 speakers. Moreover, the HLers and L2ers were both accurate with clitic placement, which is tightly interdependent upon morphosyntactic and lexicosemantic information. Clitics must be preverbal when adjoined to a finite verb ([3a] and [3b]) yet postverbal when adjoined to a nonfinite verb such as an infinitive ([4a] and [4b]). When clitics are selected by a modal verb ([5]), namely, when subject to the well-known clitic-climbing phenomenon (Rizzi, 1978), their position is optionally pre- or postverbal but not medial ([5a], [5b], and [5c]). 
(3) a. Juan lo

Juan it.cl

mira todos los días

watch. $V_{\text {fin }}$ everyday

b. ${ }^{\star J u a n ~ m i r a ~ l o ~ t o d o s ~ l o s ~ d i ́ a s ~}$

Juan watch. $V_{\text {fin }}$ it.cl everyday

"Juan watches it every day."

(4)
a. Ana canta la canción sin entederla bien
Ana sing. $V_{\text {fin }}$ the song without understand.V.INF-cl well
b. *Ana canta la canción sin la entendier bien Ana sing. $V_{\text {fin }}$ the song without it.cl understand.V.INF well "Ana sings the song without understanding it well."

(5)
a. Olga lo puede
Olga it.cl can. $V_{\text {fin }}$
comprar
buy.V.INF
$\begin{array}{lll}\text { b. Olga puede } & \text { comprarlo } \\ \text { Olga } & \text { can. } V_{\text {fin }} & \text { buy.V.INF-cl }\end{array}$
c. ${ }^{\star}$ Olga puede lo
Olga can. $V_{\text {fin }}$ it.cl
"Olga can buy it."
comprar
buy.V.INF
(Montrul, 2010a, pp.170-171)

Although the HLers and L2 speakers were both accurate with word order in sentences of type (3a) and (4a), HLers and L1 speakers produced significantly more clitic-climbing sentences ([5a] and [5b]) than the L2 speakers. Because cliticclimbing involves additional movement of clitics into functional projections, as well as more complex phrase structure than proclisis and enclisis with a lexical verb only ([3a] and [4a]), this result in Montrul (2010a) suggests HLers are capable of processing structures of greater complexity than their L2 counterparts. In a written acceptability judgment task, the HLers were found to be more like L2 speakers with respect to the following properties: rejecting accusative clitics in subject position, accepting correct and rejecting incorrect positions of clitics with finite and nonfinite verbs, rejecting clitic placement between the modal and nonfinite verb in clitic-climbing contexts, and accepting optional clitic doubling with dative objects. In contrast, the HLers were found to be more like L1 speakers with respect to properties like obligatory clitic doubling with strong DPs, acceptability of clitic left dislocation with accusative and dative clitics, as well as rejection of clitic left dislocation without dative clitics. Montrul concludes that L2ers and HLers have stable command of the syntax of clitics but that HLers show advantages for structures that are typically more frequent in spoken registers such as clitic climbing, clitic doubling, and clitic left dislocations. In the present study, knowledge of clitic 
left dislocations and the potential advantage HLers have over proficiency-matched L2ers with oral tasks is also explored.

Polinsky (2008a) conducted a small-scale study of Russian gender comparing 12 HLers of Russian dominant in English and 10 L1 speakers of Russian via an oral production and an offline grammaticality judgment test (GJT). With the exception of three participants who were born in Russia but moved to the United States between 3 and 5 years of age, the HLers were born in the United States. All of them were schooled in English, had no instruction in Russian, and were exposed to Russian until age 7 when English became the dominant language. The same type of gender agreement as in Montrul et al. (2008a) was investigated. Results showed that the L1 speakers numerically outperformed the HLers in both production and judgments, though no statistics were computed. Findings from Russian, thus, confirm that age of exposure does not confer advantages in ultimate attainment in the domain of morphosyntax.

A final study of interest is Håkansson (1995), who compared heritage and L2ers of Swedish on knowledge of nominal gender agreement and the V2 property of Swedish. In this small-scale study, 5 HLers and 6 L2ers with a wide range of linguistic profiles were tested. Of the HLers, 3 were raised and educated in the United States while the remaining 2 were raised in France and Sweden but educated in French. The L2 group included a wide range of L1s, from Swahili to Persian, which limits the generalizability of the findings. Production data were collected via a battery of production tasks eliciting use of plural and gender agreement as well as the V2 property. Simplifying the presentation slightly, the V2 property, typical of several Germanic languages, stipulates obligatory subject-verb inversion whenever nonsubject arguments occupy sentence-initial position or a yes/no question is formulated. With respect to gender agreement, L2 learners were found to be more accurate than HLers. As in Montrul et al. (2008a), the errors obtained were mostly of commission rather than omission for both the HL and L2 groups. In contrast, results for V2 revealed a striking difference between the two groups. Whereas the V2 property was applied almost categorically by the HLers, L2ers used illicit word orders at higher rates. This study, however, lacked a control group of L1 Swedish speakers, a measure of the HL and L2ers general proficiency, and inferential statistics. In summary, the evidence to date suggests the following: that HLers make similar kinds of morphological errors to L2ers; that HLers differ from L1 speakers from a quantitative point of view; and that incidence of obtaining monolingual-like syntactic competence is more likely in HLers than in L2ers. In light of this background, the present study advances our understanding of the differences and similarities in knowledge between HLers, L2ers, and L1 speakers with respect to morphosyntactic properties by extending investigation to Italian accusative clitics.

\section{The morphosyntax of Italian accusative clitics}

Clitics express functional categories and discourse functions, appear in rigidly ordered clusters (i.e., templates), are unstressed, and require a host (Spencer \& 
Table 1. Template of Italian accusative clitics

\begin{tabular}{llll} 
& & \multicolumn{2}{c}{ Gender } \\
\cline { 3 - 4 } Person & Number & Masculine & Feminine \\
\hline 1 & & $\mathrm{mi}$ & $\mathrm{mi}$ \\
\hline 2 & $\mathrm{SG}$ & $\mathrm{ti}$ & $\mathrm{ti}$ \\
3 & & $\mathrm{lo}$ & $\mathrm{la}$ \\
\hline 1 & & $\mathrm{ci}$ & $\mathrm{ci}$ \\
2 & $\mathrm{PL}$ & $\mathrm{vi}$ & $\mathrm{vi}$ \\
\hline 3 & & $\mathrm{li}$ & $\mathrm{le}$ \\
\hline
\end{tabular}

Luiz, 2015, p. 37). Italian object clitics, in particular, encode functional features such as person, number, and gender, in addition to accusative case (Table 1).

Because the gender attribute of accusative clitics is neutralized in the 1/2 SG/PL cells, 3SG/PL cells are experimentally more viable for testing knowledge of clitic forms. On a par with Spanish clitics, gender marking on Italian clitics is also a form of syntactic agreement identifying the lexical gender features encoded by the referent, as seen previously in (1) and (2).

Despite sharing pronominal properties with weak and strong pronouns, the two are distinct (Cardinaletti \& Starke, 1999). Weak and strong pronouns are nominal and pattern with full DPs for placement (i.e., postverbal), phonology (strong), and prosody (bear stress)., Clitics are, foremost, verbal insofar as they attach to a verb host with whom they form a single syntactic constituent (Belletti, 1999; Kayne, 1975; Roberts, 2010, chap. 3; Spencer \& Luiz, 2015; Sportiche, 1996). Full DPs and clitics in subject-verb-object (SVO) languages such as Italian are also unalike with respect to placement. In main finite clauses, strong accusative DPs typically appear postverbally ([6a) while clitics must surface preverbally $([6 b])$ :
a. La donna bacia
loro
the woman kisses.V.FIN
"The woman kisses them."
b. La donna li
"The woman kisses them."
the woman them.cl.3PL.MASC.ACC kisses.V.FIN

them.DP.3PL.MASC.ACC

The placement of accusative clitics, however, is far more complex than the presentation so far in that a clitic's position depends on subtle morphosyntactic and lexicosemantic information. As already seen for Spanish in (3)-(5), Italian clitics appear preverbally (i.e., proclisis), if the host verb is finite ([7a]) but postverbally (i.e., enclisis), attached to a verb, if nonfinite ([7b] and [7c]): 
(7) a. I pesci, Pietro li cucina all'aperto The fish Pietro them.cl cooks. $V_{\text {fin }}$ in-the-outdoors "the fish, Pietro cooks them outdoors."

b. I pesci, cucina-li The fish, cook.V.IMP-cl "the fish, cook them outdoors!' all'aperto! in-the-outdoors
c. I pesci bisogna cucin-ar-li all'aperto The fish, need cook.V-INF-cl in-the-outdoors "the fish need to be cooked outdoors."
d. I pesci, Pietro (li) vuole cucin-are (-li) all'aperto The fish, Pietro them.cl want.MOD cook.V-INF in-the-outdoors "The fish, Pietro wants to cook them outdoors."

e. I pesci, Pietro li fa cucin-are all'aperto dalla nonna The fish, Pietro them.cl make.CAUS cook.V-INF in-the-outdoors by-the grandma "The fish, Pietro has them cooked outdoors by grandma."
f. I pesci, Pietro li va a cucin-are all'aperto The fish, Pietro them.cl go.MOT cook.V-INF in-the-outdoors "The fish, Pietro goes to cook them outdoors."
g. I pesci, Pietro li vede cucin-are dalla nonna The fish, Pietro them.cl see.PERC cook.V-INF by-the grandma "The fish, Pietro sees the grandma cook them."

A clitic's position varies also as a function of the semantic content of its host verb ([7d] and [7e]; Rizzi, 1982). If a verb expresses modality or volition ([7d]), as in modal $+\mathrm{V}$ structures, clitic placement is optional whereas when hosted by a verb that express causality ([7e]), as in CAUS $+\mathrm{V}$ constructions, motion ([7f]), or perception $([7 \mathrm{~g}])$, it is obligatorily preverbal. Thus, the interaction between modality, causality, motion, and perception of the verb on one hand, and restrictions on clitic placement on the other, signal the syntax of accusative clitics is contingent upon lexicosemantic information. In consequence, in speech production, speakers must integrate semantic and syntactic information prior to articulation.

One analysis particularly suited to account for the differential complexity of clitic structures in (7a), (7d), and (7e) is Cardinaletti and Schlonsky (2004), who posit that verbs are hierarchically ordered based on their status as lexical, functional, and quasi-functional. Functional verbs that express semantic features like modality (e.g., volere "want," potere "can," and dovere "must") and aspect (e.g., cominciare "start" and stare per "be about to") realize functional heads and are merged higher up in the inflectional phrase region. Conversely, lexical and quasi-functional verbs such as causative (fare "make"), motion (andare "go" and venire "come"), and perception (vedere "see" and sentire "hear") verbs appear lower in the tree. Alongside this bipartite division of clitic-hosting verbs are two clitic positions, one, a high clausal position in the functional domain, and, the other, a lower position in the lexical domain (Figure 1). 


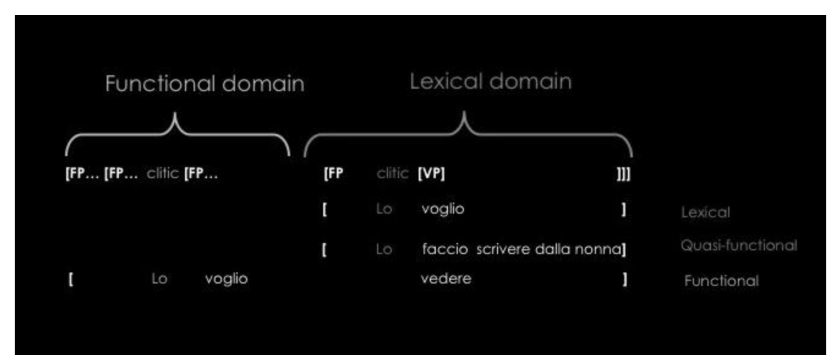

Figure 1. Syntactic complexity of accusative clitic structures with lexical, quasi-functional, and functional verbs (adapted from Cardinaletti \& Schlonsky, 2004).

The lower clitic position, labeled in dark gray in Figure 1, is only made available by lexical or quasi-functional verbs in the structure of sentences such as lo voglio, equivalent to "(I) want it" or lo faccio scrivere dalla nonna, "I'll have grandmother write it." In comparison, the higher functional clitic position labeled in the lighter gray is locus to cliticization with functional verbs in the structure of sentences like lo voglio vedere, roughly equivalent to "(I) want to see it." Only clitics in this position are subject to the well-known "clitic-climbing" phenomenon. For the purpose of this study, such an analysis of accusative clitic structures predicts greater syntactic complexity in the processing of lo voglio vedere than lo voglio and lo faccio scrivere as the latter two resort to the lexical domain only. The functional domain that involves features and merge/movement of constituents to inflectional, tense, and complementizer phrases, inter alia, is typically assumed to be harder to acquire for L2 learners (Bruhn de Garavito, 2002; Isabelli, 2004; Montrul, 2010a; Platzack, 2001) and theorized to be acquired later than lexical categories/features even in L1 acquisition (Clahsen, Eisenbeiss, \& Penke, 1996; Clahsen, Eisenbeiss, \& Vainikka, 1994; Clahsen, Penke, \& Parodi, 1993; Vainikka, 1993). Although alternative operationalizations of syntactic complexity such as interface (Platzack, 2001) and derivational (Jakubowicz, 2011) complexity exist, particularly in relation to clitic placement in Romance (Bernardini \& Timofte, 2018), Cardinaletti and Schlonsky (2004) is preferred insofar as: (a) it conforms neatly to the language acquisition literature; and (2) it allows for a specific differentiation of the complexity of structures in which Italian accusative clitics surface.

\section{Acquisition of clitics in Italian}

L2 studies of Italian have concentrated on the acquisition of clitic form and placement, some in more syntactically complex structures (Bennati, 2007; Bennati \& Matteini, 2006; Leonini, 2006; Santoro, 2007). In a study of spoken production, Leonini (2006) investigated use of accusative clitics by German-Italian speakers at intermediate proficiency levels. She found that, although placement errors are virtually absent, L2 learners display a typical non-target-like pattern, that of clitic omission (8): 
(8) a: Che cosa vuole fare la ragazza al ragazzo

"What does the girl want to do to the boy?"

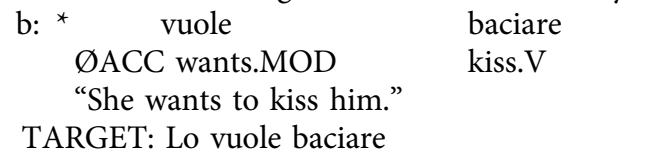

In (8) the participant ungrammatically omits the accusative clitic co-referential to the object ragazzo "boy" in (8b) where lo is categorically produced by native speakers. Omission is attested in several other studies of production (Ferrari, 2006; Guasti, Maggione, \& Vernice, 2012; Leonini \& Belletti, 2004; Serratrice, Sorace, \& Paoli, 2004).

In another study, Santoro (2007) attempted to investigate the development of accusative clitics in English-Italian late bilinguals at different levels of proficiency using an offline GJT. The procedure for this test required that participants judge the grammaticality of a stimulus sentence by pressing a CORRECT or INCORRECT button. The stimuli were accusative clitics in the structural configurations illustrated atop ([7a]-[7e]). Target items appeared in grammatical and ungrammatical conditions where ungrammaticality consisted either of a placement or a form violation. By comparison to a control group, the results show that L2 learners develop targetlike knowledge gradually from beginner to advanced levels of proficiency, reaching native-like accuracy in judgment of placement earlier than form. He observed that L2ers are less accurate at judging ungrammatical than grammatical word orders and clitic forms while native speakers show no distinction. Moreover, he found that errors with misjudgment of a clitic's form were common even at advanced levels of proficiency, especially in the ungrammatical condition. These errors were also significantly more frequent with clitic-climbing ([7d], [7e], [7f,] and $[7 \mathrm{~g}])$. Thus, in addition to confirming the finding in Leonini (2006) that clitic placement is fairly unproblematic to L2ers, Santoro's study pointed out that the syntactic complexity of clitic structures is implicated in diverging competence between natives and non-natives, especially when ungrammaticality is at stake.

L1 studies have found that the placement properties and morphological form of accusative clitics are fully acquired by Italian children before age 4 (Guasti \& Belletti, 2015, Chap. 3). Even though Italian children rarely produce incorrect word order, by age 2 , they undergo a period in which omission of accusative clitics peaks to $64 \%$, ebbing to $15 \%$ by age 3 (Schaeffer, 2000). Therefore, the phenomenology in L1 production shows interesting parallels to L2 production. Given that L1 acquisition of the morphosyntax of clitics is complete by age 4 , HL acquisition would not be expected to diverge from L1 speakers if exposure is fairly constant and takes place during from childhood. I take up this puzzling prediction here.

\section{The study}

\section{Research questions and hypotheses}

The evidence to date indicates that early exposure often leads HLers to develop L1-like competence of syntactic properties but not morphological forms 
(Håkansson, 1995; Montrul, 2010a; Montrul et al., 2008a; Polinsky, 2008a). The first question this study asks, thus, is with respect to this intriguing discrepancy, "does syntactic and morphological competence in early bilinguals diverge from L1 speakers?" To answer this question, we consider a largely understudied language, Italian, which is typologically similar to Spanish in relation to the morphosyntactic properties that have been more widely investigated. Second, given the need to better understand how syntactic complexity and patterns of use of specific structures explain divergent outcomes between L1 and HLers (Montrul, 2010a), another question this study asks is "how does syntactic complexity interact with early exposure?" This is especially crucial considering that even advanced L2ers exhibit sensitivity in judgment of the ungrammaticality of a clitic's form in structures of increased complexity (Santoro, 2007). The experiment tested the following hypotheses:

I. Syntactic knowledge of clitic constructions in adult HLers will more closely approximate that of L1 speakers than L2ers so long as exposure to Italian takes place in early childhood.

II. If syntactic complexity affects the processing of accusative clitic structures, then cliticization with lexical and causative verbs will pose less difficulty and hence be more accurate than modal verbs.

III. Morphological knowledge of a clitic's form in adult HLers will more closely approximate that of L2ers even if exposure to Italian takes place in early childhood.

Knowledge, in this context, was established by eliciting data in production, via an oral structural priming task, and judgments, via a speeded GJT.

\section{Method}

\section{Participants}

Heritage $(n=12), \mathrm{L} 2(n=12)$, and L1 $(n=18)$ speakers of Italian took part in the study. Due to the inherent diversity within HL populations, several factors were controlled via a background questionnaire and general proficiency determined via a separate test. Of the information collected via the questionnaire, I consider the following here: age of first exposure, age, mother and father's languages and origin, self-assessment as native or non-native speakers of the L1 and L2, other languages, and estimated exposure to Italian in years. All HLers were first exposed to the target language from birth (age 0 ) except 1 participant whose age of onset was 6 , but results did not deviate significantly from others. Only $1 \mathrm{HL}$ speaker had both native-speaking parents: the remainder had one native-speaking parent (5 the father, 6 the mother). All were born in Sweden from first-generation Italian-native immigrants, and none had knowledge of additional languages to the same degree as Swedish or Italian. Five of 12 self-assessed themselves as native speakers of both languages, 6 as native speakers of Swedish but not Italian, and 1 of Italian but not Swedish. Participants also self-assessed themselves on a scale from 0 
Table 2. Participant information

\begin{tabular}{|c|c|c|c|c|c|c|c|c|c|c|}
\hline \multirow[b]{2}{*}{ Groups } & \multirow[b]{2}{*}{$N$} & \multicolumn{2}{|c|}{ Age } & \multicolumn{3}{|c|}{ Proficiency } & \multicolumn{2}{|c|}{ AFE } & \multicolumn{2}{|c|}{ EE in years } \\
\hline & & $M$ & Range & $M$ & $S D$ & Range & M & Range & M & Range \\
\hline $\mathrm{HL}$ & 12 & 32 & $16-52$ & 71 & 12 & $57-89$ & 0 & - & 22 & $8-52$ \\
\hline L2 & 12 & 44 & $28-54$ & 75 & 11 & $61-95$ & 18 & $13-38$ & 11 & $2-27$ \\
\hline L1 & 18 & 24 & $21-35$ & 86 & 6 & $75-95$ & 0 & - & 24 & 21-35 \\
\hline
\end{tabular}

Note: AFE, age of first exposure. EE, estimated exposure to Italian. L1, monolinguals. HL, heritage speakers. L2, L2 learners.

(no proficiency), to 5 (native-level proficiency) with respect to their ability in the four languages skills in both languages. The HLers average scores for Italian were 3.75 in reading, 3.42 in speaking, 3.00 in writing, and 3.75 in listening, while for Swedish these were 5.00 in reading, 5.00 in speaking, 4.92 in writing, and 4.92 in listening. The estimated mean exposure to Italian in their lifetime was 23 years, and all participants reported speaking Italian on a daily basis at time of testing. Half of the sample received some instruction in the mother tongue as children, and all had had periodic visits to their home country in their lifetime. Two HLers were educated to a doctoral level, 4 had masters degrees in Italian language or literature, 4 had or were studying for completion of an Italian bachelor degree in language or literature, and the remaining 2 younger speakers had just completed high school and were attending mother tongue instruction. The L2 group were all born and raised in Sweden, and all self-assessed themselves as native speakers of Swedish. Their average scores for self-assessment in the two languages were 3.08 in reading, 2.75 in speaking, 2.75 in writing, and 3.25 in listening for Italian, in contrast to 4.83 in reading, 4.92 in speaking, 4.83 in writing, and 4.92 in listening for Swedish. All of the L2ers except for 1 had paid periodic visits to Italy and 4 had even completed a bachelor degree there. Half of the L2ers were Italian language instructors at different levels of the school system whereas another 4 were students of Italian language and literature at the bachelor level at a local university. They had an estimated mean exposure of 11 years to Italian and mean age of first exposure of 18. The L1 speakers of Italian were all born and raised in the Italian region of Veneto and recruited among 3rd- and 4th-year undergraduate students at the University of Venice Ca' Foscari. The choice of Veneto was guided by a need to minimizze effects of dialectal variation on clitic placement preferences, even though not expected.

All participants completed a separate proficiency test, a short cloze test that was used in other studies of German HLers of Italian (Kupisch, Barton, Bianchi, \& Stangen, 2012). To best investigate ultimate attainment, the heritage and L2 groups were recruited as proficient as possible in Italian. Scores for the three groups were out of 100: $\mathrm{HL}$, mean $=71, S D=12$, range $=57-89$; $\mathrm{L} 2$, mean $75, S D=11$, range $61-95$; $\mathrm{L} 1$, mean $=86, S D=6$, range $=75-95$. An independent samples $t$ test indicated the HL and L2 groups did not differ significantly for proficiency (two tailed), $t(21)=2.07, p=.43$. Participant information is summarized in Table 2 . 


\section{Measures}

\section{Priming task}

A variant of traditional structural priming tasks was selected in order to measure the strength of a grammatical representation. Structural priming is a paradigm widely used to define the robustness of a syntactic representation in a speaker's competence (Bernolet, Hartsuiker, \& Pickering, 2013; Hartsuiker \& Bernolet, 2015; Jackson \& Ruf, 2016; Kaschak, Kutta, \& Jones, 2006; Mahowald, Futrell, \& Gibson, 2016). According to Bernolet et al. (2013), for instance, structural priming is a measure of implicit learning in both L1 and L2 populations and a "valid tool to investigate the development and the degree of abstraction of syntactic representations" (p. 289). Structural priming is the well-known tendency of speakers to repeat and hearers to reuse a structure previously processed in the input for purposes of production or comprehension relative to one or more structures with the same meaning. To exemplify, upon hearing, reading, speaking, or writing a passive sentence such as the mechanic mended the car, one is more likely to utter the passive the patient was cured by the doctor rather than its equivalent active form the doctor cured the patient or any other structure conveying the same meaning. Robust evidence of priming effects have been found for different constructions (Bock, 1986; Branigan, Pickering, \& McLean, 2005; Chang, Bock, \& Goldberg, 2003; Cleland \& Pickering, 2003; Ferreira, 2003; Griffin \& Weinstein-Tull, 2003; Hartsuiker \& Westenberg, 2000; Scheepers, 2003), L1s (Cai, Pickering, Yan, \& Branigan, 2011; Hartsuiker \& Kolk, 1998; Scheepers, 2003), and L2s (Bernolet et al., 2013; Hawkins, Althobaiti, \& Ma, 2012; Mercan, 2016; Romano, 2016, 2018) across languages (e.g., Hartsuiker, Pickering, \& Veltkamp, 2004), in both spoken and written language (Bock, 1986; Pickering \& Branigan, 1998), between speaking and writing (Cleland \& Pickering, 2006), and in language comprehension (Arai, Van Gompel, \& Scheepers, 2007; Branigan et al., 2005; Traxler, 2008). Structural priming has been found to tap syntactic representations that are largely independent of meaning and sound (Branigan \& Pickering, 2017, but see commentaries in the same Special Issue of Behavioral and Brain Sciences for objections). As a tool, it is especially informative about the ways in which speakers represent and use abstract structure and has, on some accounts, been likened to the abstract representation assumed by generative linguists (Pickering \& Ferreira, 2008, p. 428; Jackson, 2017, for its application to L2 acquisition). One particular account of the mechanism behind priming effects - also the one endorsed in the present study - is that of implicit learning (Branigan \& Messenger, 2016; Chang, Dell, \& Bock, 2006; Dell \& Chang, 2016; Kaschak, et al., 2014), whereby both short- and long-term persistence of structure arises from implicit learning of abstract structure-building procedures. Such an account, therefore, offers good grounds for testing syntactic knowledge in L2, L1, and HL acquisition. An implicit assumption in this study is, thus, that the strength of priming effects of lexical, functional, and quasi-functional clitic structures is indicative of how robustly they are represented in an L2, HL, and L1 speaker's competence.

Three parallel versions of the task were created, each consisting of 54 prime-target sentence pairs, of which 6 were practice trials, 24 critical items, and 24 fillers. Consistent with the confederate scripting technique (Branigan, 
Pickering, \& McClean, 2000), participants first saw a picture containing a prime sentence that they were instructed to read out loud (8-s timeout). In this way, a structure was primed both aurally and visually. There followed a fixation point on the screen for $500 \mathrm{~ms}$ and a new blank screen containing a true or false comprehension question related to the picture (3-s timeout). Subsequently, a new slide containing four prompts for the target sentence appeared above a (new) matching picture. Participants were instructed to use the prompts to form a complete sentence describing the picture, which had to be spoken aloud before the trial timed out (10 s) and the next trial started. Primes and targets varied according to the three clitic structures shown in (7a), (7d), (7e), repeated in (9) for convenience:
a. I pesci, Pietro li cucina the fish.OBJ Pietro.SUBJ them.cl cooks. $V_{\text {fin }}$ "the fish, Pietro is cooking them outdoors."
all' aperto
in-the-outdoors
(Lexical)
b. I pesci, Pietro li vuole cucin-are all aperto the fish.OBJ Pietro. SUBJ them.cl want.MOD cook. $\mathrm{V}_{\text {-fin }}$ in-the-outdoors "The fish, Pietro wants to cook them outdoors." (Functional)
c. I pesci, Pietro li fa cucin-are dalla nonna the fish.OBJ Pietro.SUBJ them.cl make.CAUS cook. $\mathrm{V}_{\text {-fin }}$ by-the grandma "The fish, Pietro has them cooked by grandma."
(Quasi-functional)

The three prime types had structure OBJ SUBJ CL VP PP, differing minimally for the VP phrase, which was a single lexical V in (9a) but periphrastic in (9b) and (9c). Three versions of each item were created, but all participants saw only one version of each. There was no lexical overlap between the words in the prime and the prompts for the target sentence, which included, in this order, a bare noun object, a bare noun subject, a verb in the infinitive form, and a fully formed PP. In the functional and quasi-functional conditions, no verb other than the infinitive form of the expected nonfinite verb in the VP was offered as prompt. Prime and target verbs were semantically and lexically unrelated as this overlap has been shown to promote priming in L2ers (Bernolet et al., 2013). Target objects were equally split for masculine and feminine gender. A contrast in the object's feature set of the prime and target sentences was always maintained so that the sets differed by one feature. For instance, if the object of the prime bore MASC and SG features, the object of the target bore MASC.PL or FEM.SG. This choice was made in order to avoid facilitating retrieval of the referent's features in the target by effect of priming. The fillers, held constant across the three versions of the task, primed 24 sentences equally divided between two structures: transitives $(k=12)$ and reflexives $(k=12)$. These structures acted as distracters (see Cai, Pickering, Wang, \& Branigan, 2015, for a similar design). Prime-target pairs were always separated by a filler trial and conditions alternated. The order of presentation of trials was automatically randomized for each participant. A full list of prime-target sentence pairs can be found in Appendix A. Separate pictures were designed for all prime and target sentences. All pictures were black-and-white or grayscale drawings depicting the subject, object, and action of the sentence. In the causative condition, the picture 
Lexical

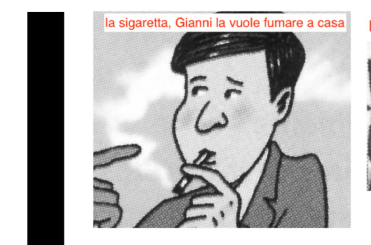

Functional

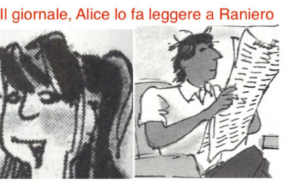

Quasi-functional

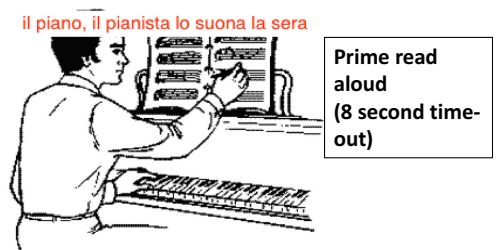

\section{Fixation $(500 \mathrm{~ms})$}

True or False question ( 3 seconds)
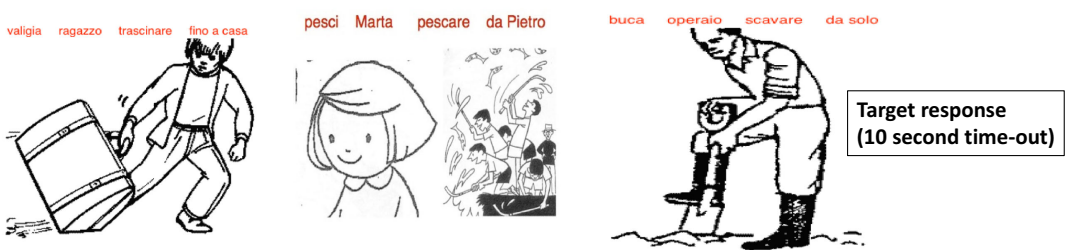

Figure 2. Sample trial for three levels of syntactic complexity in the priming task. Photos are taken with permission from the International Picture Naming Project (Szekely et al., 2004), Heaton (1966), and Van Patten, Lee, and Ballman (1992).

additionally depicted an agent. The format of the trials is graphically summarized in Figure 2.

\section{Speeded GJT}

The purpose of selecting a GJT was to elicit more explicit knowledge of clitic forms in relation to structure compared to the priming task. In a manner faithful to Santoro (2007) and similar GJTs used to test knowledge of clitics in L2ers (Duffield \& White, 1999; Montrul, 1996), the task presented participants items in both grammatical and ungrammatical conditions to be judged as correct or incorrect. One difference to previous versions of this task is that an additional response/ button, labeled "not sure," was available. Another difference was that decision times for (un)grammaticality were recorded and responses timed out after 5 . The task consisted of the same 48 target and filler sentences as priming task version 1, with the exception that each target sentence was designed in a grammatical and ungrammatical condition, totaling 96 target items $(48 \times 2)$. The targets alternated between two parallel versions of the task so that no participant saw the same item in both conditions in any one version. Each ungrammatical sentence consisted of only one error related to the clitic's form, namely, gender in either a SG or a PL context ( $l a$ for $l o$, and vice versa, $l i$ for $l e$, and vice versa). Targets also varied according to the three clitic structures as in the priming task. The order of presentation of items was automatically randomized for each participant so that fillers and targets alternated and the same structure condition would not appear consecutively (e.g., causative $>$ filler $>$ causative). The task began with instructions before three sample items with correct answers were explained. Eight practice items followed before the experiment began. Participants were informed of a 5-s timeout per response and 
instructed to press 1 for "correct," 2 for "incorrect," or 3 for "not sure." Sentences appeared all at once. After a response was recorded or a sentence timed-out, there followed a fixation point on the screen for $500 \mathrm{~ms}$ and a new blank screen containing a new sentence.

\section{Procedure}

Experiments were run on two Lenovo ThinkPad 4173DC9 laptops in designated lab spaces at the University of Venice Ca' Foscari and Stockholm University. Both tasks were designed and the experiment run on E-Prime experimental software 2.0. Participants' oral responses in the structural priming task were recorded via the laptops' in-built microphone and transcribed by the author, a native speaker of Italian. Participants completed the linguistic background questionnaire and placement test online prior to arriving at the testing lab for administration of the priming task and GJT, always in that order. The priming task took 33 min while the GJT lasted on average 5 min depending on individual participant speed. At the end of the experiment, participants were rewarded with a $\$ 10$ voucher for the university library's bookstore.

\section{Results}

\section{Priming task}

To test the three hypotheses, morphological and syntactic analyses were conducted. The following were identified as the most frequent response categories in the morphological analysis: correct; clitic omission as in la classe Raniero Ø insegna la sera "the class Raniero teaches at night" or Raniero insegna la classe la sera "Raniero teaches the class at night"; an incorrect co-referent as in Pietro la mamma la fa richiamare dal padre "Pietro the mother has her scolded from the father," where the clitic's form la.SG.FEM is well formed but anaphorically linked to the incorrect referent mamma "mother"; misagreement as in La classe Raniero lo insegna la sera "the class Raniero it teaches at night," where SG.MASC lo misagrees with its SG.FEM referent classe; other structures such as passive structures Pietro è richiamato dal padre al rientro "Pietro is scolded by the father upon returning" and reflexives Pietro dal padre si fa richiamare al rientro "Pietro from the dad has himself scolded upon returning"; and missing data for incomplete or no answers. Priming effects were not considered for the coding. Results of the morphological analysis are given in Table 3.

Overall, morphological accuracy is similar in the heritage and L2 groups whose correct scores were near $60 \%$ while the most frequent type of error, omission, approaches $32 \%$. This result was expected from the late bilinguals (recall Leonini, 2006) and also compatible with the errors of Italian children between 2 and 3 years of age. The L1 speakers' scores are considerably higher for accuracy and lower for omission. Noteworthy also is the low rate of gender assignment and person/number agreement errors, which are absent in the monolingual group and as low as $1.7 \%$ in the other groups. To ascertain whether differences were significant, a mixed-effects logistic regression model was fit to the data with the lme4 
Table 3. Morphological analysis of clitic use in the oral structure priming task

\begin{tabular}{|c|c|c|c|c|c|c|}
\hline \multirow[b]{2}{*}{ Response } & \multicolumn{2}{|c|}{ L1 $(n=18)$} & \multicolumn{2}{|c|}{$\mathrm{HL}(n=12)$} & \multicolumn{2}{|c|}{$\mathrm{L} 2(n=12)$} \\
\hline & Count & $\%$ & Count & $\%$ & Count & $\%$ \\
\hline Correct & $357 / 418$ & 85.5 & $173 / 281$ & 61.7 & $164 / 281$ & 59 \\
\hline Omission & $48 / 418$ & 11.5 & $95 / 281$ & 33.9 & $91 / 281$ & 32 \\
\hline Incorrect co-referent & $3 / 418$ & 0.7 & $5 / 281$ & 1.7 & $11 / 281$ & 3.9 \\
\hline Misagreement & - & - & $5 / 281$ & 1.7 & $5 / 281$ & 1.7 \\
\hline Other & $10 / 418$ & 2.3 & $3 / 281$ & 1 & $10 / 281$ & 3.4 \\
\hline
\end{tabular}

Note: Missing data: L1, 14/432 (3.2 \%); HL, 7/288 (2.4\%); L2, 7/288 (2.4\%).

Table 4. Pairwise comparisons for accuracy in the production of clitics

\begin{tabular}{lcccc}
\hline Contrasts & Estimate & $S E$ & Wald $z$ & $p$ \\
\hline Intercept & -2.872 & 0.56 & -5.096 & $<.001$ \\
\hline L1 vs. HL & -2.125 & 0.81 & -2.623 & $<.01$ \\
\hline L1 vs. L2 & -1.934 & 0.81 & -2.381 & $=.01$ \\
\hline HL vs. L2 & -0.195 & 0.87 & 0.219 & $>.05$ \\
\hline
\end{tabular}

Note: L1, monolinguals. $\mathrm{HL}$, heritage speakers. L2, L2 learners.

package in $\mathrm{R}$ version 3.6 (R Development Core Team, 2013). The dependent variable was coded as a binary response representing log odds of a correctly/incorrectly formed clitic where the latter were the sum of omission, incorrect co-referent, and misagreement cases in Table 3. Group was entered as a fixed-effect factor with three levels while participants and items were the random effects. Random slopes were not included in this and subsequent models due to sample size, bearing in mind that maximizing the random effects structure does not always entail best fit (Matushek, Kliegl, Vasishth, Baayen, \& Bates, 2017). To check whether differences between groups were significant, a simple effects analysis with treatment coding was computed by progressively switching the reference level (relevel() function) to create the necessary contrasts for each level of the group factor. Pairwise comparisons (Table 4) reveal that the L1 speakers were significantly more likely to produce a correct clitic than the HLers and the L2ers, but the latter did not differ from each other. These results, thus, are consistent with Hypothesis III, namely, that age of exposure does not confer advantages to ultimate attainment in HLers insofar as more purely morphological properties of clitics are concerned.

The goal of the syntactic analysis was to determine the strength of priming for each clitic structure investigated. Sentences were coded as primed when the target followed the same structure as the prime and both object and subject were present. Nonprimed responses were the sum of targets that took an alternative structure to the prime as in a causative or modal $+\mathrm{V}$ for a lexical prime, and so on. The presence 
Table 5. Priming effects in the oral structure priming task

\begin{tabular}{|c|c|c|c|c|c|c|c|c|c|c|c|c|}
\hline \multirow[b]{3}{*}{ Structure } & \multicolumn{4}{|c|}{ L1 $(n=18)$} & \multicolumn{4}{|c|}{$\mathrm{HL}(n=12)$} & \multicolumn{4}{|c|}{$\mathrm{L} 2(n=12)$} \\
\hline & \multicolumn{2}{|c|}{ Primed } & \multicolumn{2}{|c|}{$\begin{array}{l}\text { Non- } \\
\text { primed }\end{array}$} & \multicolumn{2}{|c|}{ Primed } & \multicolumn{2}{|c|}{$\begin{array}{l}\text { Non- } \\
\text { primed }\end{array}$} & \multicolumn{2}{|c|}{ Primed } & \multicolumn{2}{|c|}{$\begin{array}{l}\text { Non- } \\
\text { primed }\end{array}$} \\
\hline & Count & $\%$ & Count & $\%$ & Count & $\%$ & Count & $\%$ & Count & $\%$ & Count & $\%$ \\
\hline Lexical (cl-V) & $131 / 139$ & 94 & $8 / 139$ & 6 & $82 / 95$ & 86 & $13 / 95$ & 14 & $88 / 93$ & 95 & $15 / 93$ & 5 \\
\hline $\begin{array}{l}\text { Functional } \\
\text { (cl-causative) }\end{array}$ & $130 / 137$ & 95 & $7 / 130$ & 5 & $68 / 91$ & 75 & $23 / 91$ & 25 & $69 / 86$ & 80 & $17 / 86$ & 20 \\
\hline $\begin{array}{l}\text { Quasi-functional } \\
(\text { cl-MOD + V) }\end{array}$ & $88 / 141$ & 62 & $53 / 88$ & 38 & $33 / 93$ & 35 & $60 / 93$ & 65 & $23 / 90$ & 25 & $67 / 90$ & 75 \\
\hline
\end{tabular}

Note: Missing data: L1, 15/432 (3.4 \%); HL, 9/288 (3.1\%); L2, 19/288 (6.5\%). Boldfacing is for emphasis purposes only.

Table 6. Pairwise comparisons for general priming effects by group

\begin{tabular}{lcccc}
\hline Contrasts & Estimate & $S E$ & Wald $z$ & $p$ \\
\hline L1 vs. HL & -2.347 & 0.65 & -3.588 & $<.001$ \\
\hline L1 vs. L2 & -2.166 & 0.66 & -3.239 & $=.001$ \\
\hline HL vs. L2 & -0.188 & 0.55 & -0.343 & $>.05$ \\
\hline
\end{tabular}

Note: L1, monolinguals. HL, heritage speakers. L2, L2 learners.

of a clitic was not considered for the coding. Incomplete or no responses were coded as missing data. Table 5 reports the effect of priming by group and complexity.

Overall, the strength of priming is numerically highest in the L1 group where functional and lexical verb structures show the strongest priming effect. The heritage and L2 groups, however, also show a bias for these structures compared to the quasi-functional whose priming strength is as low as $25 \%$ in the L2 group. To ascertain whether differences were significant, a mixed-effects logistic regression model was fit to the data with the lme4 package in $\mathrm{R}$ version 3.6 ( $\mathrm{R}$ Development Core Team, 2013). A binary dependent variable measured the log odds of a primed/nonprimed response in the priming task and a correct/incorrect answer in the GJT. Two fixed effects, group and complexity, with three levels each, and two random effects for participants and items were included. A type III analysis of variance (ANOVA) analysis was conducted via the car package and anova() function, which utilizes a likelihood ratio test to determine main effects and interactions from the model without any need for coding. ${ }^{2}$ The ANOVA finds a main effect of group, $\chi^{2}(2)=916.91$, $p<.001$, complexity, $\chi^{2}(2)=946.61, p<.001$, and a significant interaction between the two, $\chi^{2}(4)=714.89, p<.001$. Thus, all terms were retained in the model considered for further analysis.

An analysis of simple effects at the group level computed in the same way as the previous analysis (Table 6) reveals that L1 speakers are significantly more likely to be primed than the HLers and L2ers, but no difference was observed between the HLers and L2ers, indicating a quantitative difference between L1 speakers and both 


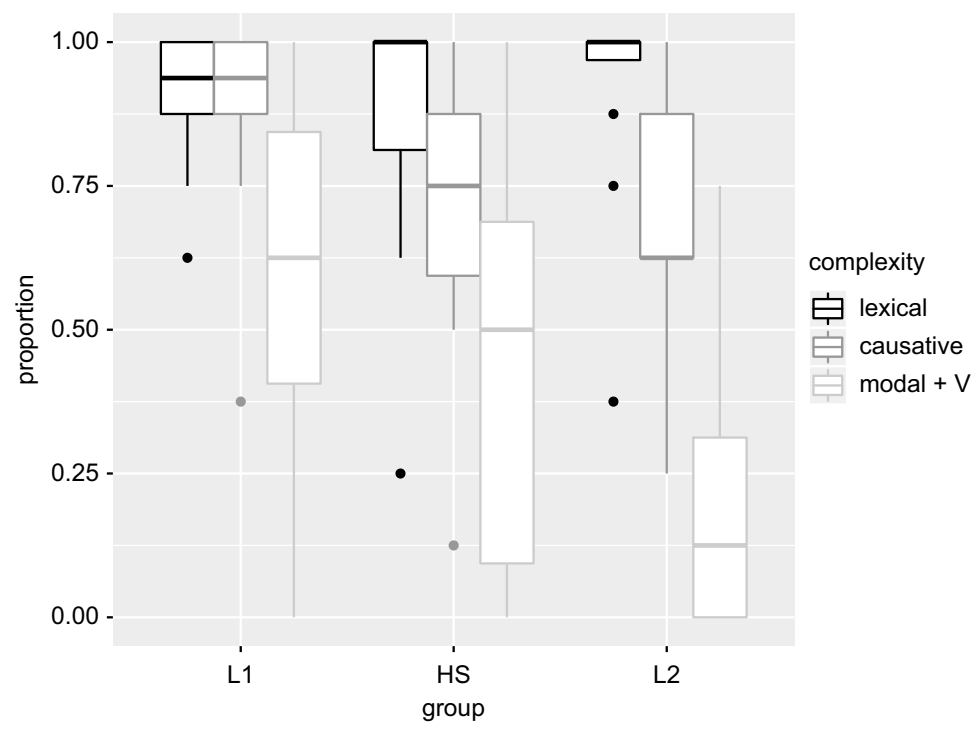

Figure 3. Boxplot representing the proportion of repeated primed structures by group and complexity expressed.

L2ers and HLers. However, the main interaction reveals qualitative similarities between the L1 and HLers (Figure 3).

While the L1 speakers show generally higher proportions of repeating lexical and causative followed by modal $+\mathrm{V}$ constructions, the trend in the HL and L2 group follows the pattern lexical $>$ causative $>$ modal $+V$ constructions. A simple effect analysis of the interaction between group and complexity is presented in Table 7 .

The L1 speakers did not differ significantly in the likelihood of priming at the lexical and causative levels but did show higher probability of priming at the lexical than the modal $+\mathrm{V}$, as well as the causative versus modal $+\mathrm{V}$ level. The same pattern is found for the HL group but not the L2 group, where all contrasts were significant. A similarity in priming strength between the L1 and HL groups is corroborated by a study of the simple effects of group at the modal $+\mathrm{V}$ level, also shown in Table 7. The HL group did not differ from the L1 speakers while the L2 group did, and the HLers and L2ers differed from each other. In summary, while L1 speakers showed quantitative differences to the other groups by virtue of greater overall priming strength, they also showed a qualitative similarity to HLers in the effects of syntactic complexity, partially consistent with Hypothesis I. In contrast stronger priming at the lexical and causative levels compared to the modal $+\mathrm{V}$ level are consistent with Hypothesis II, that the latter involves processing more complex structure.

\section{GJT}

The GJT measured accuracy in judgment of grammatical and ungrammatical forms of 3SG/PL, MASC/FEM clitics at each level of the syntactic complexity factor. This 
Table 7. Pairwise comparisons for priming effects in the group by complexity interaction

\begin{tabular}{llcccc}
\hline Reference level & Contrasts & Estimate & SE & Wald z & $p$ \\
\hline L1 & Lex vs. Caus & 0.381 & 0.62 & 0.608 & $>.05$ \\
& Lex vs. Mod + V & -2.875 & 0.47 & -6.026 & $<.001$ \\
& Caus vs. Mod + V & -3.256 & 0.54 & -6.012 & $<.001$ \\
\hline HL & Lex vs. Caus & 0.726 & 0.42 & 1.724 & $>.05$ \\
& Lex vs. Mod + V & -2.497 & 0.42 & -5.951 & $<.001$ \\
& Caus vs. Mod + V & 1.771 & 0.37 & 4.704 & $<.001$ \\
\hline L2 & Lex vs. Caus & -1.375 & 0.52 & -2.609 & $<.05$ \\
& Lex vs. Mod + V & -4.402 & 0.53 & -8.190 & $<.001$ \\
& Caus vs. Mod + V & -3.028 & 0.42 & -7.190 & $<.001$ \\
\hline Mod + V & HL vs. L1 & 0.890 & 0.48 & 1.844 & $>.05$ \\
& HL vs. L2 & -1.123 & 0.54 & -2.066 & $>.05$ \\
\hline & L1 vs. L2 & -2.013 & 0.50 & -3.992 & $<.001$ \\
\hline
\end{tabular}

Note: L1, monolinguals. HL, heritage speakers. L2, L2 learners. Lex, lexical. Caus, causative. Mod $+\mathrm{V}=$ modal $+\mathrm{V}$. $p$ values from multiple comparisons were Tukey adjusted.

Table 8. Responses in the grammaticality judgment task by group and complexity: Grammatical condition

\begin{tabular}{|c|c|c|c|c|c|c|c|c|c|c|c|c|}
\hline \multirow[b]{3}{*}{ Structure } & \multicolumn{4}{|c|}{ L1 $(n=18)$} & \multicolumn{4}{|c|}{$\mathrm{HL}(n=12)$} & \multicolumn{4}{|c|}{$\mathrm{L} 2(n=11)$} \\
\hline & \multicolumn{2}{|c|}{ Correct } & \multicolumn{2}{|c|}{ Incorrect } & \multicolumn{2}{|c|}{ Correct } & \multicolumn{2}{|c|}{ Incorrect } & \multicolumn{2}{|c|}{ Correct } & \multicolumn{2}{|c|}{ Incorrect } \\
\hline & Count & $\%$ & Count & $\%$ & Count & $\%$ & Count & $\%$ & Count & $\%$ & Count & $\%$ \\
\hline Lexical (cl-V) & $121 / 130$ & 93 & $9 / 130$ & 7 & $76 / 88$ & 86 & $12 / 88$ & 14 & $75 / 81$ & 93 & $6 / 81$ & 7 \\
\hline $\begin{array}{l}\text { Functional } \\
\text { (cl-causative) }\end{array}$ & $116 / 125$ & 93 & $9 / 125$ & 7 & $70 / 86$ & 81 & $16 / 86$ & 19 & $67 / 73$ & 92 & $6 / 73$ & 8 \\
\hline $\begin{array}{l}\text { Quasi-functional } \\
(c l-M O D+V)\end{array}$ & $119 / 129$ & 92 & $10 / 129$ & 8 & $73 / 82$ & 89 & $9 / 82$ & 11 & $75 / 80$ & 94 & $5 / 80$ & 6 \\
\hline
\end{tabular}

Note: Missing data: L1, 48/432 (11\%); HL, 32/288 (11\%); L2, 30/264 (11\%). Not sure responses=9. Boldfacing is for emphasis purposes only. One L2 learner was excluded as the person obtained perfect scores.

enabled a direct comparison to the findings for L2ers in Santoro (2007) and evidence to address Hypotheses II and III. Results are reported in Table 8 and 9.

Across the results in Table 8 and 9, the L1 speakers show higher correct counts than the other groups, ranging between 91 and 95. The HLers and L2ers's correct counts are seemingly higher in the grammatical (Table 8 ) than the ungrammatical (Table 9) condition: percentage ranges of 81-89 in the HL group and 92-94 in the L2 group in the grammatical condition contrast with 77-81 in the HL group and 74-78 in the L2 group in the ungrammatical condition. To ascertain whether the differences were statistically significant, a logistic regression predicting a binary dependent variable measuring the log odds of a correct/incorrect response from 
Table 9. Responses in the grammaticality judgment task by group and complexity: Ungrammatical condition

\begin{tabular}{|c|c|c|c|c|c|c|c|c|c|c|c|c|}
\hline \multirow[b]{3}{*}{ Structure } & \multicolumn{4}{|c|}{$\mathrm{L} 1(n=18)$} & \multicolumn{4}{|c|}{$\mathrm{HL}(n=12)$} & \multicolumn{4}{|c|}{$\mathrm{L} 2(n=11)$} \\
\hline & \multicolumn{2}{|c|}{ Correct } & \multicolumn{2}{|c|}{ Incorrect } & \multicolumn{2}{|c|}{ Correct } & \multicolumn{2}{|c|}{ Incorrect } & \multicolumn{2}{|c|}{ Correct } & \multicolumn{2}{|c|}{ Incorrect } \\
\hline & Count & $\%$ & Count & $\%$ & Count & $\%$ & Count & $\%$ & Count & $\%$ & Count & $\%$ \\
\hline Lexical (cl-V) & $130 / 137$ & 95 & $7 / 137$ & 5 & $61 / 75$ & 81 & $14 / 75$ & 19 & $56 / 71$ & 78 & $15 / 71$ & 22 \\
\hline $\begin{array}{l}\text { Functional } \\
\text { (cl-causative) }\end{array}$ & $119 / 128$ & 93 & $9 / 128$ & 7 & $62 / 83$ & 75 & $21 / 83$ & 25 & $56 / 74$ & 76 & $18 / 74$ & 24 \\
\hline $\begin{array}{l}\text { Quasi-functional } \\
\text { (cl-MOD + V) }\end{array}$ & $116 / 128$ & 91 & $12 / 128$ & 9 & $61 / 79$ & 77 & $18 / 79$ & 23 & $61 / 82$ & 74 & $21 / 82$ & 26 \\
\hline
\end{tabular}

Note: Missing data: L1, 39/432 (9\%); HL, 51/288 (17\%); L2, 35/264 (13\%). Not sure responses=9. Boldfacing is for emphasis purposes only.

Table 10. Pairwise comparisons for accuracy by grammaticality and group in the grammatical judgment task

\begin{tabular}{llcccc}
\hline Reference level & Contrasts & Estimate & SE & Wald $z$ & $p$ \\
\hline L1 & GR vs. UGR & -0.041 & 0.42 & -0.09 & $>.05$ \\
\hline HL & GR vs. UGR & -0.836 & 0.38 & -2.200 & $<.05$ \\
\hline L2 & GR vs. UGR & -1.613 & 0.43 & -3.710 & $<.001$ \\
\hline UGR & L1 vs. HL & -1.800 & 0.58 & -3.070 & $<.01$ \\
& L1 vs. L2 & -1.727 & 0.60 & -2.860 & $<.01$ \\
& L1 vs. L2 & -0.072 & 0.62 & -0.110 & $>.05$ \\
\hline
\end{tabular}

Note: L1, monolinguals. HL, heritage speakers. L2, L2 learners. GR, grammatical. UGR, ungrammatical.

two fixed effects, group (Level 3 factor) and grammaticality (Level 2 factor), and two random effects for participants and items, was modeled in the same way as the priming task. A main effect of grammaticality, $\chi^{2}(1)=4.839, p<.05$, no main effect of group, $\chi^{2}(2)=0.251, p>.05$, but a significant interaction, $\chi^{2}(2)=11.66$, $p<.01$, were found. Given the presence of a main interaction, all terms were retained in the model considered for further analysis. Table 10 reports the relevant contrasts of the interaction analysis.

The analysis, conducted in the same the same way as the priming task, indicates that the HLers and L2ers only are likely to be more accurate in the grammatical than the ungrammatical condition. These differences are also supported at the group level insofar as the L1 speakers outperformed both the HLers and the L2ers in the ungrammatical condition, despite the latter two groups not differing significantly from each other. Turning to the effects of complexity, an analysis was conducted separately in the grammatical and ungrammatical data sets with group and complexity as fixed effects. In the ungrammatical condition, a main effect of group, $\chi^{2}(2)=7.61, p<.05$, no effect of complexity, $\chi^{2}(2)=2.20, p>.05$, and no interaction between the two, $\chi^{2}(4)=3.186, p>.05$, was present. Thus, only the group 
Table 11. Pairwise comparisons for accuracy by group on the grammatical judgment task's ungrammatical items

\begin{tabular}{lcccc}
\hline Contrasts & Estimate & SE & Wald $z$ & $p$ \\
\hline L1 vs. HL & -2.569 & 0.95 & -2.680 & $<.01$ \\
\hline L1 vs. L2 & 1.824 & 0.98 & 1.859 & $=.06$ \\
\hline HL vs. L2 & -0.745 & 0.98 & -0.758 & $>.05$ \\
\hline
\end{tabular}

Note: L1, monolinguals. HL, heritage speakers. L2, L2 learners.

term was retained in the model considered for further analysis. The effect of group amounts to higher odds of a correct response in the L1 than the HL group, the difference between the L1 and L2 groups approaching significance, and no difference between the HL and L2 groups (Table 11).

In the grammatical condition, no effects were found. To summarize, the results show similar accuracy rates for judgments of clitic form in the three groups in the grammatical condition. In the ungrammatical condition, the L2 and HL groups were significantly less likely to select correct responses than L1 speakers, consistent with Hypothesis III, which predicted no advantage for early exposure. Furthermore, these effects were not mitigated by the syntactic complexity of the sentences in which clitics participate, contra Santoro (2007) and Hypothesis II.

\section{Discussion}

The study examined two core issues in a strand of conversation in second language acquisition centered on heritage languages. First, it asked whether the ultimate attainment of syntactic and morphological knowledge in HLers speakers differs from L1 speakers' despite a similar scheduling of first exposure to native input. It was first hypothesized that early exposure would be associated with more L1-like outcomes for the syntax of clitic constructions (Hypothesis I). Results from a structural priming task partially confirmed this hypothesis: while quantitative differences were found between HLers and the L1 group for the overall strength of priming, a closer look at clitic constructions by type revealed similar patterns. In particular, two similarities were found. For one, heritage and L1 speakers exhibit significantly stronger priming effects in lexical and causative constructions such as I pesci, Pietro li cucina all'aperto "the fish, Pietro cooks them outdoors" and I pesci, Pietro li fa cucinare all'aperto dalla nonna "the fish, Pietro has them cooked outdoors by grandma" than modal + V I pesci, Pietro li vuole cucin-are all'aperto "the fish, Pietro wants to cook them outdoors." By comparison, L2ers exhibit the strongest priming effects in the lexical verb, followed by causative, and modal + $\mathrm{V}$ conditions. In turn, significant differences were found at the group level, between the L2ers and L1 speakers but not the HLers and L1 speakers for the strength of priming of modal constructions. Overall, then, these findings suggest that the abstract representation of clitic structures are qualitatively more similar between early bilinguals and more monolingual speakers, pace Bayram, Prada y Cabo, and Rothman (2018, p. 190) and Kupisch and Rothman (2016, p. 565), who 
maintain qualitative differences also at a syntactic level. These results are also consistent with the finding in Montrul (2010a) that less proficient HLers process more complex structures in a more L1-like manner compared to proficiency-matched L2ers. However, given that the structural priming task in the present study and the production task in Montrul (2010a) were both oral, HLers show an advantage over L2ers for this modality in Italian and Spanish. It should also be noted that any quantitative differences found between the monolingual and bilingual groups could also be due to general differences in average proficiency levels (Table 2), a difference common to all of the previous studies reviewed herein comparing HL, L2, and L1 groups.

A second hypothesis, based on previous findings of heritage Spanish, was that early exposure does not confer advantages for more morphological aspects of clitics (Hypothesis III). HLers and L2ers were, therefore, suspected to exhibit similar gender assignment errors in production by overgeneralizing masculine forms to feminine contexts. Moreover, based on previous research on L2 Italian, the early and late bilinguals tested were expected to show similar patterns of clitic omission in production and greater difficulty in judging ungrammatical clitic forms. Generally speaking, Hypothesis III was borne out by the data. In the priming task, early and late bilinguals alike omitted clitics at comparable rates $(32 \%-33 \%)$ while omission in the L1 group was substantially lower (11\%). The L1 versus heritage speaker divide for morphological competence was further corroborated by the GJT data where both the heritage and L2 groups were significantly worse than L1 speakers at judging clitic forms when they were ungrammatical. Let us recall that an ungrammaticality effect was predicted at least in the late bilinguals based on Santoro (2007). One result, however, did not show an age-of-exposure effect on morphological competence, namely, that gender assignment errors would be found in production. While both HLers and L2ers of Spanish have been shown to consistently overextend assignment of masculine to feminine gender (Bruhn de Garavito \& White, 2002; McCarthy, 2007; Montrul et al., 2008a), this phenomenon was not reproducible in L2 Italian where gender assignment errors were as low as $5 \%$. The relative accuracy in use of accusative clitics by the HLers is also at odds with O'Grady, Lee, and Choo (2001), who claim that early bilinguals are especially vulnerable to incomplete acquisition in areas that are highly susceptible to input frequencies such as inflectional morphology. A possible explanation for this cross-linguistic difference in gender assignment errors rests with the higher average proficiency level for the bilingual speakers in the present study compared to the studies of Spanish reviewed previously. Higher proficiency levels may be associated with more L1-like knowledge of clitic forms and complete acquisition of the functional features encoded by clitics. Another possibility is positive transfer from Swedish to Italian, as the former instantiates a type of grammatical gender that may have facilitated the acquisition of gender assignment in the latter. What is one to make of the omission, however? If Italian children cease to omit clitics by age 4 (Guasti \& Belletti, 2015) and HLers undergo similar exposure to Italian children in childhood, the source of omission in the HLers must be tied to language development at later stages or purely linguistic factors. For one, the HLers speakers tested may have undergone a phase of attrition with their stronger language, Swedish, a clitic-less language. This hypothesis, however, is not confirmed by 
Spanish heritage language research (Montrul, 2004; Silva-Corvalán, 1994) where clitics have not been reported as subject to attrition. Nor is it supported by the English-Spanish data in Montrul (2010a) where clitic omission was not documented despite English lacking clitics. Another possibility is that the ultimate attainment of a morphosyntactic property absent in the stronger language impinges on the weaker one. This form of cross-linguistic influence, however, which is postulated to take place unidirectionally from the stronger to the weaker language (Paradis \& Genesee, 1996), is unverifiable in the present study as an additional group of late and early bilingual speakers of a stronger language that allows clitics would be necessary. Cross-linguistic influence as a source of divergence between monolingual and HLers speakers in the morphological domain, thus, is currently being explored in a follow-up project. Perhaps the most plausible account of the omission observed in the bilingual groups based on the present data is interface vulnerability, a phenomenon proposed originally by Sorace and Filiaci (2006) and discussed later with application to HLers by Dominguez (2009, p. 274). More specifically, properties that tap into and require the interaction of more than one grammatical domains (e.g., syntax and morphology, syntax and pragmatics) are likely to lead to divergence between bilingual and monolingual speakers (Sorace \& Filiaci, 2006). The OBJ SUBJ CL VP PP structures tested in this study effectively involve clitic-left dislocation, that is, the topicalization of an object by displacement to a preverbal position in the left periphery of the clause (Rizzi, 1997). Given that topicalization requires knowledge of discourse functions, it is plausible that the bilingual speakers in this study found use of clitics more problematic in clitic-left dislocated structures. Interface vulnerability, however, reflects only marginal difficulties integrating pragmatic knowledge with the realization of accusative-marked pronouns in the data set. As typically reported for L1 children (Guasti \& Belletti, 2015, p. 88), the L2 and HLers in this study did not omit full NPs when required by transitive verbs in the filler trials, nor did they produce strong pronouns. The absence of these errors in the priming task, therefore, points clearly to a more marginal difficulty with topicalization at the level of discourse pragmatics.

The second question asked by this study was whether the syntactic complexity of clitic structures and early exposure conspire to explain divergent outcomes between L1 and HLers. In the case of Italian accusative clitics, L2ers' grammatical intuitions have been found to be significantly worse than L1 speakers' in structures where cliticization involves causative and modal + V constructions (Santoro, 2007). Assuming the analysis of cliticization with lexical, quasi-functional, and functional verbs by Cardinaletti and Schlonsky (2004), it was hypothesized that lexical and causative verbs are less difficult to process than modal $+\mathrm{V}$ for all types of speakers (Hypothesis II). Results from the structural priming task supported this hypothesis insofar as all three groups conformed to this pattern. Such consistency, paired with the low levels of agreement errors in use of clitics by the bilingual groups, suggests that they have access to the relevant abstract structure (i.e., lexical and functional domains of Cardinaletti \& Schlonsky, 2004) and features necessary for cliticization in Italian. However, as pointed out above, the L1 and heritage language speakers who were exposed to native input from birth did not show a significant difference in priming effects for sentences in the lexical and quasi-functional verb conditions, indicating a qualitative similarity between these two groups and a fairly 
monolingual-like quality on the part of the HLers. This is neatly consistent with Cardinaletti and Schlonsky's theoretical claim that these constructions only require access to a lower lexical domain for clitic placement. Findings from the priming task, therefore, confirm that early exposure leads to more L1-like attainment in the processing of cliticization. Results from the GJT, in contrast, did not show such an advantage. The three groups did not differ for the effects of syntactic complexity on their grammatical intuitions neither in the grammatical nor in the ungrammatical condition, contra Santoro (2007). Instead, both bilingual groups performed significantly worse than the more monolingual group in the ungrammatical condition, consistent with Hypothesis III and partially in line with Santoro (2007), suggesting a bilingual's ability to detect ungrammaticality in a weaker language does not improve with early exposure. The lack of complexity effects may be due to the more explicit nature of grammatical intuitions that tap into metalinguistic knowledge of the language, in contrast to structural priming, which represents a more implicit measure of linguistic knowledge. In consequence, the findings suggest that L1-like attainment of more explicit knowledge of clitic forms and cliticization is achievable even when acquisition takes place after childhood. The differential success in ultimate attainment observed in the implicit and explicit measures for late bilinguals warrants future research based on larger groups than the present study.

\section{Conclusion}

This study has shown a discrepancy in the degree of ultimate attainment of morphological versus syntactic knowledge in HLers. While L2ers and HLers are more similar in their attainment of morphological forms, HLers approximate the representation of syntactic structures of L1 speakers more closely. The study has also revealed striking similarities between HLers and L1 speakers in the way syntactic complexity modulates the strength of structural priming, which speaks in favor of a cognitive advantage for early language exposure.

Acknowledgments. I thank three anonymous reviewers and the editor at Applied Psycholinguistics for their valuable input on the manuscript. I would also like to express my gratitude to Giuliana Giusti, Giulia Bencini, and Anna Cardinaletti for their valuable help with data collection and aspects of methodology and theory. I am indebted to Rakel Österberg and Fanny Forsberg-Lundell for their help with the manuscript and overall project. I thank Ben Bolker and Rusell Lenth for statistical advice on the multiple comparisons adjustment included in Table 7. Finally, I am also in acknowledgment of the comments received from the audiences at Lund University's SOL, especially Petra Bernardini, Verner Egerland, and Silvia Gargiulo, as well as many individuals at Stockholm University's Centre for Bilingualism and Department of Romance Languages and Studies who provided insightful comments and suggestions. All errors remaining are mine.

\section{NOTES}

1. Throughout, I will refer to more monolingual speakers as L1 speakers for purely expository reasons, without the intention of dismissing that some HLers possess sufficient linguistic abilities in their heritage language to also qualify as L1 speakers.

2. Rather than running a series of likelihood ratio tests comparing models with and without the term of interest to detect main effects and interactions, the same result can be achieved via the car::Anova function from the car package v.3.0-3 (Fox, 2019) by specifying the type of ANOVA test, II or III, to be run in 
parentheses. For the sake of replication, please note that nonbinary factors need be sum-coded prior to entering the full model into car::Anova.

\section{References}

Arai, M., Van Gompel, R. P. G., \& Scheepers, C. (2007). Priming ditransitive structures in comprehension. Cognitive Psychology, 54, 218-250.

Bayram, F., Prada, J., Pascual y Cabo, D., \& Rothman, J. (2018). Why should formal linguistic approaches to heritage language acquisition be linked to heritage language pedagogies? In P. P. Trifonas \& T. Aravossitas (Eds.), Handbook of research and practice in heritage language education. Cham, Switzerland: Springer.

Belletti, A. (1999). Italian/Romance clitics: Structure and derivation. In H. van Riemsdijk (Ed.), Clitics in the language of Europe (pp. 543-579). Berlin: de Gruyter.

Bennati, E. (2007). Object clitic climbing in adult L2 Italian. Nanzan Linguistics: Special Issue, 3, 1-21.

Bennati, E., \& Matteini, S. (2006). Object clitic climbing in L2 learners of Italian. In A. Belletti, E. Bennati, C. Chesi, E. DiDomenico, \& I. Ferrari (Eds.), Proceedings of GALA 2005 (pp. 35-48). Cambridge: Cambridge Scholars Publishing.

Bernardini, P., \& Timofte, M. (2018). Cross-linguistic influence in the bilingual acquisition of object clitics: A matter of complexity? In Syntactic complexity from a language acquisition perspective (pp. 206-232). Cambridge: Cambridge Scholars Publishing.

Bernolet, S., Hartsuiker, R. J., \& Pickering, M. J. (2013). From language-specific to shared syntactic representations: The influence of second language proficiency on syntactic sharing in bilinguals. Cognition, 127, 287-306.

Bley-Vroman, R. (1990). The logical problem of foreign language learning. Linguistic Analysis, 20, 3-49.

Bock, J. K. (1986). Syntactic persistence in language production. Cognitive Psychology, 18, 355-387.

Branigan, H. P., \& Messenger, K. (2016). Consistent and cumulative effects of syntactic experience in children's sentence production: Evidence for error-based implicit learning. Cognition, 157, 250-256.

Branigan, H. P., \& Pickering, M. (2017). Structural priming and the representation of language. Behavioral and Brain Sciences, 40, E313. doi:10.1017/S0140525X17001212

Branigan, H. P., Pickering, M. J., \& Mclean, A. A. (2000). Priming prepositional-phrase attachment during language comprehension. Journal of Experimental Psychology: Learning, Memory, and Cognition, 31, 468-481.

Branigan, H. P., Pickering, M. J., \& McLean, J. F. (2005). Priming prepositional-phrase attachment during comprehension. Journal of Experimental Psychology: Learning, Memory and Cognition, 31, 468-481.

Bruhn de Garavito, J. (2002). Verb raising in Spanish: A comparison of early and late bilinguals. In B. Skarabela, S. Fish, \& A. Do (Eds.), BUCLD 26: Proceedings of the 26th annual Boston University Conference on Language Development (pp. 84-94). Somerville, MA: Cascadilla Press.

Bruhn de Garavito, J., \& White, L. (2002). The second language acquisition of Spanish DPs: The status of grammatical features. The Acquisition of Spanish Morphosyntax: The L1/L2 Connection. 153-178.

Cai, Z. G., Pickering, M. J., Wang, R., \& Branigan, H. P. (2015). It is there whether you hear it or not: Syntactic representations of missing arguments. Cognition, 136, 255-267.

Cai, Z. G., Pickering, M. J., Yan, H., \& Branigan, H. P. (2011). Lexical and syntactic representations in closely related languages: Evidence from Mandarin and Cantonese. Journal of Memory and Language, 65, 431-445.

Cardinaletti, A., \& Schlonsky, U. (2004). Clitic positions and restructuring in Italian. Linguistic Inquiry, 35, 519-557.

Cardinaletti, A., \& Starke, M. (1999). The typology of structural deficiency: A case study of three classes of pronouns. In H. Van Riemsdijk (Ed.), Clitics in the languages of Europe (pp. 145-233). Berlin: de Gruyter.

Carreira, M., \& Kagan, O. (2018). Heritage language education: A proposal for the next fifty years. Foreign Language Annals, 51, 152-168.

Chang, F., Bock, J. K., \& Goldberg, A. E. (2003). Can thematic roles leave traces of their places? Cognition, 90, 29-49.

Chang, F., Dell, G. S., \& Bock, K. (2006). Becoming syntactic. Psychological Review, 113, 234-272. 
Chung, E. (2018). Second and heritage language acquisition of Korean case drop. Bilingualism: Language and Cognition, 21(1), 63-79. doi:10.1017/S1366728916001218

Clahsen, H., Eisenbeiss, S., \& Penke, M. (1996). Lexical learning in early syntactic development. In H. Clahsen (Ed.), Generative perspectives on language acquisition: Empirical findings, theoretical considerations, crosslinguistic comparisons (pp. 129-59). Amsterdam: Benjamins.

Clahsen, H., Eisenbeiss, S., \& Vainikka, A. (1994). The seeds of structure: A syntactic analysis of the acquisition of case marking. In T. Joekstra \& B. D. Schwartz (Eds.), Language acquisition studies in generative grammar (pp. 85-118). Amsterdam: Benjamins.

Clahsen, H., \& Muysken, P. (1986). The UG paradox in L2 acquisition. Second Language Research, 5, 1-29.

Clahsen, H., Penke, M., \& Parodi, T. (1993). Functional categories in early child German. Language Acquisition, 3, 395-429.

Cleland, A. A., \& Pickering, M. J. (2003). The use of lexical and syntactic information in language production: Evidence from the priming of noun-phrase structure. Journal of Memory and Language, 49, 214-230.

Cleland, A. A., \& Pickering, M. J. (2006). Do writing and speaking employ the same syntactic representations? Journal of Memory and Language, 54, 185-198.

DeKeyser, R. (2000). The robustness of critical period effects in second language acquisition. Studies in Second Language Acquisition, 22, 499-534.

DeKeyser, R. (2003). Implicit and explicit learning. In C. Doughty \& M. Long (Eds.), The handbook of second language acquisition (pp. 313-348). Malden, MA: Blackwell.

Dell, G. S., \& Chang, F. (2016). The P-chain: Relating sentence production and its disorders to comprehension and acquisition. Philosophical Transactions of the Royal Society of London. Series B, Biological Sciences, 369, 20120394. doi:10.1098/rstb.2012.0394

Dominguez, L. (2009). Charting the route of bilingual development: Contributions from heritage speakers' early acquisition. International Journal of Bilingualism, 13, 271-287.

Duffield, N., \& White, L. (1999). Assessing L2 knowledge of Spanish clitic placement: Convergent methodologies. Second Language Research, 15, 133-160.

Ferrari, I. (2006). Acquisition of object clitics in Italian by two German/Italian bilingual children. In A. Belletti, E. Bennati, C. Chesi, E. DiDomenico, \& I. Ferrari (Eds.), Proceedings of GALA 2005 (pp. 173-183). Cambridge: Cambridge Scholars Publishing.

Ferreira, V. S. (2003). The persistence of optional complementizer production: Why saying "that" is not saying "that" at all. Journal of Memory and Language, 48, 379-398.

Flores, C., Kupisch, T., \& Rinke, E. (2019). Linguistic foundations of heritage language development from the perspective of Romance languages in Germany. Amsterdam: Springer.

Fox, J. (2019). car: Companion to Applied Regression. R package version 3.0-3. https://r-forge.r-project.org/ projects/car/

Griffin, Z. M., \& Weinstein-Tull, J. (2003). Conceptual structure modulates structural priming in the production of complex sentences. Journal of Memory and Language, 49, 537-555.

Guasti, M. T., \& Belletti, A. (2015). The acquisition of Italian morphosyntax and its interfaces in different modes of acquisition. Amsterdam: Benjamins.

Guasti, M. T., Maggioni, A., \& Vernice, M. (2012). Disturbi specifici del linguaggio, bilinguismo e acquisizione di L2 [Specific language impairment, bilingualism and L2 acquisition]. In R. Grassi (Ed.), Nuovo contesti d'acquisizione e insegnamento: L'italiano nelle realtá plurilingui. Atti del convegno CIS (pp. 189-197). Perugia: Guerra Edizioni.

Håkansson, G. (1995). Syntax and morphology in language attrition. A study of five bilingual expatriate Swedes. International Journal of Applied Linguistics, 5, 153-171.

Hartsuiker, R. J., \& Bernolet, S. (2015). The development of shared syntax in second language learning. Bilingualism: Language and Cognition, 20, 219-234.

Hartsuiker, R. J., \& Kolk, H. H. (1998). Syntactic persistence in Dutch. Language and Speech, 41, 143-184.

Hartsuiker, R. J., Pickering, M. J., \& Veltkamp, E. (2004). Is syntax separate or shared between languages? Cross-linguistic syntactic priming in Spanish-English bilinguals. Psychological Science, 15, 409-414.

Hartsuiker, R. J., \& Westenberg, C. (2000). Word order priming in written and spoken sentence production. Cognition, 75, B27-B39.

Hawkins, R., Althobaiti, M., \& Ma, Y. (2012). Eliminating grammatical function assignment from hierarchical models of speech production: Evidence from the conceptual accessibility of referents. Applied Psycholinguistics, 35, 677-707. 
Hawkins, R., \& Chan, C. (1997). The partial accessibility of Universal Grammar in second language acquisition: The "failed formal features hypothesis." Second Language Research, 13, 187-226.

Heaton, B. (1966). Composition through pictures. London: Longman.

Hyltenstam, K., \& Abrahamsson, N. (2003). Maturational constraints in SLA. In C. Doughty \& M. Long (Eds.), The handbook of second language acquisition (pp. 539-588). Malden, MA: Blackwell.

Isabelli, C. A. (2004). The acquisition of the null subject parameter properties in SLA: Some effects of positive evidence in a naturalistic learning context. Hispania, 87, 150-162.

Jackson, C. N. (2017). Second language structural priming: A review of recent research and directions for future research. Second Language Research, 34, 539-552.

Jackson, C. N., \& Ruf, H. (2016). The priming of word order in second language German. Applied Psycholinguistics, 38, 315-345.

Jakubowicz, C. (2011). Measuring derivational complexity: New evidence from typically developing and SLI learners of L1 French. Lingua, 121, 339-351. doi: 10.1016/j.lingua.2010.10.006

Kanno, K., Hasegawa, T., Ikeda, K., Ito, Y., \& Long, M. H. (2008). Relationships between prior languagelearning experience and variation in the linguistic profiles of advanced English-speaking learners of Japanese. In D. Brinton, O. Kagan, \& S. Bauckus (Eds.), Heritage language education: A new field emerging (pp. 165-181). New York: Routledge.

Kaschak, M. P., Kutta, T. J., \& Coyle, J. M. (2014). Long and short term cumulative structural priming effects. Language, Cognition and Neuroscience, 29, 728-743.

Kayne, R. (1975). French syntax. Cambridge, MA: MIT Press.

Kondo-Brown, K. (Ed.). (2006). Heritage language development: Focus on East Asian immigrants. Amsterdam: Benjamins.

Kupisch, T., Barton, D., Bianchi, G., \& Stangen, I. (2012). The HABLA-Corpus (German-French and German-Italian). In T. Schmidt \& K. Wörner (Eds.), Multilingual corpora and multilingual corpus analysis. Hamburg: Benjamins.

Kupisch, T., \& Rothman, J. (2016). Terminology matters! Why difference is not incompleteness and how early child bilinguals are heritage speakers. International Journal of Bilingualism, 22, 564-582.

Leonini, C. (2006). The acquisition of object clitics and definite articles: Evidence from Italian as L2 and L1. Unpublished PhD dissertation, University of Siena.

Leonini, C., \& Belletti, A. (2004). Adult L2 acquisition of Italian clitic pronouns and subject inversion/VS structures. In J. van Kampen \& S. Baauw (Eds.), Proceedings of GALA 2004 (pp. 293-304). Utrecht: LOT.

Long, M. (1990). Maturational constraints on language development. Studies in Second Language Acquisition, 12, 251-285.

Mahowald, K., Futrell, A. J. R., \& Gibson, E. (2016). A meta-analysis of syntactic priming experiments. Journal of Memory and Language, 91, 5-27.

Matuschek, H., Kliegl, R., Vasishth, S., Baayen, H., \& Bates, D. (2017). Balancing type I error and power in linear mixed models. Journal of Memory and Language, 94, 305-315.

McCarthy, C. (2007). Morphological variability in second language Spanish. Unpublished doctoral dissertation. McGill University, Montreal, Canada.

Meisel, J. (1997). The acquisition of the syntax of negation in French and German: Contrasting first and second language development. Second Language Research, 13, 227-263.

Mercan, G. (2016). Structural priming in L2 Turkish. In A. Gürel (Ed.), Second language acquisition of Turkish (pp. 313-332). Amsterdam: Benjamins.

Montrul, S. (1996). The second language acquisition of dative case: From absolute L1 influence to optionality. In Proceedings of the 20th Boston University Conference on Language Development (pp. 506-517). Somerville, MA: Cascadilla Press.

Montrul, S. (2004). Subject and object expression in Spanish heritage speakers: A case of morpho-syntactic convergence. Bilingualism: Language and Cognition, 7, 1-18.

Montrul, S. (2008). Incomplete acquisition in bilingualism. Re-examining the age factor. Amsterdam: Benjamins.

Montrul, S. (2009). Re-examining the fundamental difference hypothesis: What can early bilinguals tell us? Studies in Second Language Acquisition, 31, 225-257.

Montrul, S. (2010a). How similar are L2 learners and heritage speakers? Spanish clitics and word order. Applied Psycholinguistics, 31, 167-207. 
Montrul, S. (2010b). Dominant language transfer in Spanish L2 learners and heritage speakers. Second Language Research, 26, 293-925.

Montrul, S. (2016). The acquisition of heritage languages. Cambridge: Cambridge University Press.

Montrul, S. A., Bhatt, R., \& Girju, R. (2015). Differential object marking in Spanish, Hindi, and Romanian as heritage languages. Language, 91, 564-610.

Montrul, S. A., \& Bowles, M. A. (2009). Back to basics: Differential object marking under incomplete acquisition in Spanish heritage speakers. Bilingualism, 12, 363-383.

Montrul, S., Foote, R., \& Perpiñán, S. (2008a). Gender agreement in adult second language learners and Spanish heritage speakers: The effects of age and context of acquisition. Language Learning, 58, 503-553.

Montrul, S., Foote, R., \& Perpiñán, S. (2008b). Knowledge of wh-movement in Spanish L2 learners and heritage speakers. In M. Almazán, J. Bruhn de Garavito, \& E. Valenzuela (Eds.), Selected papers from the 8th Hispanic Linguistics Symposium (pp. 93-106). Somerville, MA: Cascadilla Press.

Montrul, S., \& Perpiñán, S. (2011). Assessing differences and similarities between instructed L2 learners and heritage language learners in their knowledge of Spanish Tense-Aspect and Mood (TAM) Morphology. Heritage Language Journal, 8, 90-133.

O'Grady, W., Lee, M., \& Choo, M. (2001). The acquisition of relative clauses by heritage and nonheritage learners of Korean as a second language. A comparative study. Journal of Korean Language Education, 12, 283-294.

Paradis, M. (2004). A neurolinguistic theory of bilingualism. Amsterdam: Benjamins.

Paradis, J., \& Genesee, F. (1996). Syntactic acquisition in bilingual children: Autonomous or interdependent? Studies in Second Language Acquisition, 18, 1-25.

Pickering, M. J., \& Branigan, H. P. (1998). The representation of verbs: Evidence from syntactic priming in language production. Journal of Memory and Language, 39, 633-651.

Pickering, M. J., \& Ferreira, V. S. (2008). Structural priming: A critical review. Psychological Bulletin, 134, 427-449.

Platzack. C. (2001). The vulnerable C-domain. Brain and Language, 77, 364-377.

Polinsky, M. (2008a). Heritage language narratives. In D. Brinton, O. Kagan, \& S. Bauckus (Eds.), Heritage language education. A new field emerging (pp. 149-164). New York: Routledge.

Polinsky, M. (2008b). Russian gender under incomplete acquisition. Heritage Language Journal, 6. Retrieved May 20, 2009, from http://www.heritagelanguages.org/

Polinsky, M. (2018). Heritage languages and their speakers. Cambridge: Cambridge University Press.

Potowski, K., Jegerski, J., \& Morgan-Short, K. (2009). The effects of instruction on linguistic development in Spanish heritage language speakers. Language Learning, 59, 537-579.

Putnam, M., \& Sánchez, L. (2013). What's so incomplete about incomplete acquisition? A prolegomenon to modeling heritage language grammars. Linguistic Approaches to Bilingualism, 3, 476-506.

R Development Core Team. (2013). R: A language and environment for statistical computing. Vienna: Foundation for Statistical Computing. Retrieved from http://www.R-project.org

Rizzi, L. (1978). A restructuring rule in Italian syntax. In S. J. Keyser (Ed.), Recent transformational studies in European languages (pp. 113-158). Cambridge, MA: MIT Press.

Rizzi, L. (1982). A restructuring rule. In Issues in Italian syntax (pp. 1-76). Dordrecht: Foris.

Rizzi, L. (1997). The fine structure of the left-periphery. In L. Haegeman (Ed.), Elements of grammar (pp. 281-337). Dordrecht: Kluwer.

Roberts, I. (2010). A deletion analysis of null subjects. In T. Biberauer, A. Holmberg, I. Roberts, \& M. Sheehan (Eds.), Parametric variation: Null subjects in minimalist theory. New York: Cambridge University Press.

Romano, F. (2016). Syntactic planning of English genitives in L1 and L2 production: The Animacy Rule Model. Lingua, 184, 104-121.

Romano, F. (2018). The basis continuity hypothesis of L1 to L2 production. Second Language Research. Advance online publication.

Santoro, M. (2007). Second language acquisition of Italian accusative and dative clitics. Second Language Research, 23, 37-50.

Schachter, J. (1990). On the issue of completeness in second language acquisition. Second Language Research, 6, 93-124.

Schaeffer, J. C. (2000). The acquisition of direct object scrambling and clitic placement: Syntax and pragmatics. Amsterdam: Benjamins. 
Scheepers, C. (2003). Syntactic priming of relative clause attachments: Persistence of structural configuration in sentence production. Cognition, 89, 179-205.

Serratrice, L., Sorace, A., \& Paoli, S. (2004). Crosslinguistic influence at the syntax-pragmatics interface, subjects and objects in English-Italian bilingual and monolingual acquisition. Bilingualism: Language and Cognition, 7, 183-206.

Silva-Corvalan, C. (1994). Language contact and change: Spanish in Los Angeles. Oxford: Oxford University Press.

Silva-Corvalán, C. (2014). Bilingual language acquisition: Spanish and English in the first six years. EuroAmerican Journal of Applied Linguistics and Languages, 2. doi:10.21283/2376905X.3.60

Smith, N., \& Tsimpli, I. (1995). The mind of a savant. Language learning and modularity. Oxford: Blackwell.

Sorace, A., \& Filiaci, F. (2006). Anaphora resolution in near-native speakers of Italian. Second Language Research, 22, 339-368.

Spencer, A., \& Luì, A. R. (2015). Clitics. New York: Cambridge University Press.

Sportiche, D. (1996). Clitic constructions. In J. Rooryck \& L. Zaring (Eds.), Phrase structure and the lexicon (pp. 213-287). Dordrecht: Kluwer.

Szekely, A., Jacobsen, T., D’Amco, S., Devescovi, A., Andonova, E., Herron, D., . . Bates, E. (2004). A new online resource for psycholinguistic studies. Journal of Memory and Language, 51, 247-250.

Traxler, M. J. (2008). Lexically independent priming in online sentence comprehension. Psychonomic Bulletin \& Review, 15, 149-155.

Vainikka, A. (1993). Case in the development of English syntax. Language Acquisition, 3, 257-325.

VanPatten, B., Lee, J. F., \& Ballman, T. L. (1992). Sabias que? (2nd ed.). New York: Routledge.

\section{Appendix A. Priming task versions}

\section{Target items: From left to right, syntactic complexity is alternated for the same item across the lexical, quasi-functional, and functional condition in each version of the task.}

\begin{tabular}{|c|c|c|c|c|}
\hline Item & Type & Version 1 & Version 2 & Version 3 \\
\hline 1 & Prime & $\begin{array}{l}\text { Le bollette, Alice le paga } \\
\text { ogni mese }\end{array}$ & $\begin{array}{l}\text { Le bollette, Alice le deve } \\
\text { pagare ogni mese }\end{array}$ & $\begin{array}{l}\text { le bollette, Raniero le fa } \\
\text { pagare da Alice }\end{array}$ \\
\hline 1 & Target & $\begin{array}{l}\text { La pasta, Alice la mangia } \\
\text { tutti i giorni }\end{array}$ & $\begin{array}{l}\text { La pasta, Alice la vuole } \\
\text { mangiare tutti i giorni }\end{array}$ & $\begin{array}{l}\text { la pasta, Raniero la fa } \\
\text { mangiare da Alice }\end{array}$ \\
\hline 2 & Prime & $\begin{array}{l}\text { La lezione, Alice la deve } \\
\text { seguire ogni Lunedi' }\end{array}$ & $\begin{array}{l}\text { La lezione, la } \\
\text { professoressa la fa } \\
\text { seguire ad Alice }\end{array}$ & $\begin{array}{l}\text { La lezione, Alice la segue } \\
\text { ogni Lunedi }\end{array}$ \\
\hline 2 & Target & $\begin{array}{l}\text { Il compito, Alice lo deve } \\
\text { scrivere in classe }\end{array}$ & $\begin{array}{l}\text { Il compito, l'insegnante lo } \\
\text { fa scrivere ad Alice }\end{array}$ & $\begin{array}{l}\text { Il compito, Alice lo scrive in } \\
\text { classe }\end{array}$ \\
\hline 3 & Prime & $\begin{array}{l}\text { L'italiano, il professore lo } \\
\text { fa parlare ad Alice }\end{array}$ & $\begin{array}{l}\text { L'italiano, Alice lo parla } \\
\text { con il professore }\end{array}$ & $\begin{array}{l}\text { L'italiano, Alice lo vuole } \\
\text { parlare con il professore }\end{array}$ \\
\hline 3 & Target & $\begin{array}{l}\text { La pagella, Alice la fa } \\
\text { guardare a Gianni }\end{array}$ & $\begin{array}{l}\text { La pagella, Gianni la } \\
\text { guarda per Alice }\end{array}$ & $\begin{array}{l}\text { La pagella, Gianni la deve } \\
\text { guardare per Alice }\end{array}$ \\
\hline 4 & Prime & $\begin{array}{l}\text { Il libro, Alice lo studia al } \\
\text { mattino }\end{array}$ & $\begin{array}{l}\text { Il libro, Alice lo deve } \\
\text { studiare al mattino }\end{array}$ & $\begin{array}{l}\text { Il libro, il professore lo fa } \\
\text { studiare ad Alice }\end{array}$ \\
\hline 4 & Target & $\begin{array}{l}\text { La casa, Alice la pulisce il } \\
\text { weekend }\end{array}$ & $\begin{array}{l}\text { La casa, Alice la deve } \\
\text { pulire il weekend }\end{array}$ & $\begin{array}{l}\text { La casa, Raniero la fa } \\
\text { pulire ad Alice }\end{array}$ \\
\hline
\end{tabular}


(Continued)

\begin{tabular}{|c|c|c|c|c|}
\hline Item & Type & Version 1 & Version 2 & Version 3 \\
\hline 5 & Prime & $\begin{array}{l}\text { Il cappotto, Aurora lo } \\
\text { vuole indossare dopo il } \\
\text { lavoro }\end{array}$ & $\begin{array}{l}\text { Il cappotto, Raniero lo fa } \\
\text { indossare ad Aurora }\end{array}$ & $\begin{array}{l}\text { Il cappotto, Aurora lo } \\
\text { indossa dopo il lavoro }\end{array}$ \\
\hline 5 & Target & $\begin{array}{l}\text { La classe, Raniero la vuole } \\
\text { insegnare la sera }\end{array}$ & $\begin{array}{l}\text { La classe, il collega la fa } \\
\text { insegnare a Raniero }\end{array}$ & $\begin{array}{l}\text { La classe, Raniero la } \\
\text { insegna la sera }\end{array}$ \\
\hline 6 & Prime & $\begin{array}{l}\text { Il giornale, Alice lo fa } \\
\text { leggere a Raniero }\end{array}$ & $\begin{array}{l}\text { Il giornale, Raniero lo } \\
\text { legge la sera }\end{array}$ & $\begin{array}{l}\text { Il giornale, Raniero lo deve } \\
\text { leggere la sera }\end{array}$ \\
\hline 6 & Target & $\begin{array}{l}\text { La musica, Alice la fa } \\
\text { ascoltare a Raniero }\end{array}$ & $\begin{array}{l}\text { La musica, Raniero la } \\
\text { ascolta la sera }\end{array}$ & $\begin{array}{l}\text { La musica, Raniero la deve } \\
\text { ascoltare la sera }\end{array}$ \\
\hline 7 & Prime & $\begin{array}{l}\text { I vestiti, Alice li compra } \\
\text { durante i saldi }\end{array}$ & $\begin{array}{l}\text { I vestiti, Alice li vuole } \\
\text { comprare durante i saldi }\end{array}$ & $\begin{array}{l}\text { I vestiti, Raniero li fa } \\
\text { comprare da Alice }\end{array}$ \\
\hline 7 & Target & $\begin{array}{l}\text { Lo strumento, Marco lo } \\
\text { suona il fine settimana }\end{array}$ & $\begin{array}{l}\text { Lo strumento, Marco lo } \\
\text { vuole suonare il fine } \\
\text { settimana }\end{array}$ & $\begin{array}{l}\text { Lo strumento, Alice lo fa } \\
\text { suonare da Marco }\end{array}$ \\
\hline 8 & Prime & $\begin{array}{l}\text { La sigaretta, Gianni la } \\
\text { vuole fumare a casa }\end{array}$ & $\begin{array}{l}\text { La sigaretta, Massimo la } \\
\text { fa fumare a Gianni }\end{array}$ & $\begin{array}{l}\text { La sigaretta, Gianni la fuma } \\
\text { a casa }\end{array}$ \\
\hline 8 & Target & $\begin{array}{l}\text { La birra, Marco la vuole } \\
\text { provare al bar }\end{array}$ & $\begin{array}{l}\text { La birra, Alice la fa } \\
\text { provare a Marco }\end{array}$ & $\begin{array}{l}\text { La birra, Marco la prova al } \\
\text { bar }\end{array}$ \\
\hline 9 & Prime & $\begin{array}{l}\text { Il giardino, Alice lo fa } \\
\text { pulire da Michele }\end{array}$ & $\begin{array}{l}\text { Il giardino, Michele lo } \\
\text { pulisce la mattina }\end{array}$ & $\begin{array}{l}\text { Il giardino, Michele lo deve } \\
\text { pulire la mattina }\end{array}$ \\
\hline 9 & Target & $\begin{array}{l}\text { La lavagna, Alice la fa } \\
\text { usare da Anna }\end{array}$ & $\begin{array}{l}\text { La lavagna, Anna la usa } \\
\text { tutte le lezioni }\end{array}$ & $\begin{array}{l}\text { La lavagna, Anna la deve } \\
\text { usare tutte le lezioni }\end{array}$ \\
\hline 10 & Prime & $\begin{array}{l}\text { La cena, Alice la prepara } \\
\text { tutte le sere }\end{array}$ & $\begin{array}{l}\text { La cena, Alice la vuole } \\
\text { preparare tutte le sere }\end{array}$ & $\begin{array}{l}\text { la cena, Raniero la fa } \\
\text { preparare ad Alice }\end{array}$ \\
\hline 10 & Target & $\begin{array}{l}\text { Il televisore, Raniero lo } \\
\text { vede la sera }\end{array}$ & $\begin{array}{l}\text { Il televisore, Raniero lo } \\
\text { vuole vedere la sera }\end{array}$ & $\begin{array}{l}\text { Il televisore, Alice lo fa } \\
\text { vedere a Raniero }\end{array}$ \\
\hline 11 & Prime & $\begin{array}{l}\text { I tramezzini, Pietro li deve } \\
\text { mangiare in tavola }\end{array}$ & $\begin{array}{l}\text { I tramezzini, Marta li fa } \\
\text { mangiare a Pietro }\end{array}$ & $\begin{array}{l}\text { I tramezzini, Pietro li } \\
\text { mangia in tavola }\end{array}$ \\
\hline 11 & Target & $\begin{array}{l}\text { il pane, Marta lo deve } \\
\text { affettare col coltello }\end{array}$ & $\begin{array}{l}\text { il pane, Pietro lo fa } \\
\text { affettare a Marta }\end{array}$ & $\begin{array}{l}\text { il pane, Marta lo affetta col } \\
\text { coltello }\end{array}$ \\
\hline 12 & Prime & $\begin{array}{l}\text { l'elefante, la mamma lo fa } \\
\text { pesare dal carabiniere }\end{array}$ & $\begin{array}{l}\text { l'elefante, il carabiniere lo } \\
\text { pesa al porto }\end{array}$ & $\begin{array}{l}\text { l'elefante, il carabiniere lo } \\
\text { deve pesare al porto }\end{array}$ \\
\hline 12 & Target & $\begin{array}{l}\text { I pesci, Marta li fa pescare } \\
\text { da Pietro }\end{array}$ & $\begin{array}{l}\text { I pesci, Pietro li pesca } \\
\text { dalla riva }\end{array}$ & $\begin{array}{l}\text { I pesci, Pietro li deve } \\
\text { pescare dalla riva }\end{array}$ \\
\hline 13 & Prime & $\begin{array}{l}\text { il muro, Pietro lo buca } \\
\text { da fuori }\end{array}$ & $\begin{array}{l}\text { il muro, Pietro lo deve } \\
\text { bucare da fuori }\end{array}$ & $\begin{array}{l}\text { il muro, il padre lo fa } \\
\text { bucare da Pietro }\end{array}$ \\
\hline 13 & Target & $\begin{array}{l}\text { i pesci, Pietro li cucina } \\
\text { all'aperto }\end{array}$ & $\begin{array}{l}\text { i pesci, Pietro li deve } \\
\text { cucinare all'aperto }\end{array}$ & $\begin{array}{l}\text { i pesci, il padre li fa } \\
\text { cucinare da Pietro }\end{array}$ \\
\hline 14 & Prime & $\begin{array}{l}\text { la palla, il ragazzo la deve } \\
\text { riprendere dalla buca }\end{array}$ & $\begin{array}{l}\text { la palla, Pietro la fa } \\
\text { riprendere dal ragazzo }\end{array}$ & $\begin{array}{l}\text { la palla, il ragazzo la } \\
\text { riprende dalla buca }\end{array}$ \\
\hline 14 & Target & $\begin{array}{l}\text { i sassi, il marinaio li deve } \\
\text { pesare sulla bilancia }\end{array}$ & $\begin{array}{l}\text { I sassi, il carabiniere li fa } \\
\text { pesare dal marinaio }\end{array}$ & $\begin{array}{l}\text { I sassi, il marinaio li pesa } \\
\text { sulla bilancia }\end{array}$ \\
\hline
\end{tabular}


(Continued)

\begin{tabular}{|c|c|c|c|c|}
\hline Item & Type & Version 1 & Version 2 & Version 3 \\
\hline 15 & Prime & $\begin{array}{l}\text { la mamma, Marta la fa } \\
\text { salutare da Pietro }\end{array}$ & $\begin{array}{l}\text { la mamma, Marta la } \\
\text { saluta prima del mercato }\end{array}$ & $\begin{array}{l}\text { la mamma, Marta la deve } \\
\text { salutare prima del mercato }\end{array}$ \\
\hline 15 & Target & $\begin{array}{l}\text { Pietro, la mamma lo fa } \\
\text { richiamare dal padre }\end{array}$ & $\begin{array}{l}\text { Pietro, il padre lo } \\
\text { richiama al rientro }\end{array}$ & $\begin{array}{l}\text { Pietro, il padre lo deve } \\
\text { richiamare al rientro }\end{array}$ \\
\hline 16 & Prime & $\begin{array}{l}\text { Pietro, il marinaio lo salva } \\
\text { dalle onde }\end{array}$ & $\begin{array}{l}\text { Pietro, il marinaio lo deve } \\
\text { salvare dalle onde }\end{array}$ & $\begin{array}{l}\text { Pietro, Marta lo fa salvare } \\
\text { dal marinaio }\end{array}$ \\
\hline 16 & Target & $\begin{array}{l}\text { La mappa, Pietro la legge } \\
\text { in piedi }\end{array}$ & $\begin{array}{l}\text { La mappa, Pietro la deve } \\
\text { leggere in piedi }\end{array}$ & $\begin{array}{l}\text { La mappa, la mamma la fa } \\
\text { leggere da Pietro }\end{array}$ \\
\hline 17 & Prime & $\begin{array}{l}\text { I fiori, il ragazzo li deve } \\
\text { tagliare con la forbice }\end{array}$ & $\begin{array}{l}\text { I fiori, Aurora li fa tagliare } \\
\text { dal ragazzo }\end{array}$ & $\begin{array}{l}\text { I fiori, il ragazzo li taglia } \\
\text { con la forbice }\end{array}$ \\
\hline 17 & Target & $\begin{array}{l}\text { il fuoco, l'uomo lo deve } \\
\text { accendere nella foresta }\end{array}$ & $\begin{array}{l}\text { il fuoco, Alice lo fa } \\
\text { accendere dall'uomo }\end{array}$ & $\begin{array}{l}\text { il fuoco, l'uomo lo accende } \\
\text { nella foresta }\end{array}$ \\
\hline 18 & Prime & $\begin{array}{l}\text { il pacco, Aurora lo fa } \\
\text { portare alla signorina }\end{array}$ & $\begin{array}{l}\text { il pacco, la signorina lo } \\
\text { porta in mano }\end{array}$ & $\begin{array}{l}\text { il pacco, la signorina lo } \\
\text { vuole portare in mano }\end{array}$ \\
\hline 18 & Target & $\begin{array}{l}\text { la scarpa, Alice la fa } \\
\text { prendere al cagnolino }\end{array}$ & $\begin{array}{l}\text { la scarpa, il cagnolino la } \\
\text { prende coi denti }\end{array}$ & $\begin{array}{l}\text { la scarpa, il cagnolino la } \\
\text { vuole prendere coi denti }\end{array}$ \\
\hline 19 & Prime & $\begin{array}{l}\text { il piano, il pianista lo } \\
\text { suona la sera }\end{array}$ & $\begin{array}{l}\text { il piano, il pianista lo } \\
\text { vuole suonare la sera }\end{array}$ & $\begin{array}{l}\text { il piano, Alice lo fa suonare } \\
\text { al pianista }\end{array}$ \\
\hline 19 & Target & $\begin{array}{l}\text { la buca, l'operaio la scava } \\
\text { da solo }\end{array}$ & $\begin{array}{l}\text { la buca, l'operaio la vuole } \\
\text { scavare da solo }\end{array}$ & $\begin{array}{l}\text { la buca, Raniero la fa } \\
\text { scavare all'operaio }\end{array}$ \\
\hline 20 & Prime & $\begin{array}{l}\text { il biscotto, la bimba lo } \\
\text { deve infornare lentamente }\end{array}$ & $\begin{array}{l}\text { il biscotto, la mamma lo } \\
\text { fa infornare dalla bimba }\end{array}$ & $\begin{array}{l}\text { il biscotto, la bimba lo } \\
\text { inforna lentamente }\end{array}$ \\
\hline 20 & Target & $\begin{array}{l}\text { la valigia, il ragazzo la } \\
\text { deve trascinare fino a } \\
\text { casa }\end{array}$ & $\begin{array}{l}\text { la valigia, Aurora la fa } \\
\text { trascinare dal ragazzo }\end{array}$ & $\begin{array}{l}\text { la valigia, il ragazzo la } \\
\text { trascina fino a casa }\end{array}$ \\
\hline 21 & Prime & $\begin{array}{l}\text { la lavagna, Raniero la fa } \\
\text { cancellare all'insegnante }\end{array}$ & $\begin{array}{l}\text { la lavagna, l'insegnante la } \\
\text { cancella dopo la lezione }\end{array}$ & $\begin{array}{l}\text { la lavagna, l'insegnante la } \\
\text { deve cancellare dopo la } \\
\text { lezione }\end{array}$ \\
\hline 21 & Target & $\begin{array}{l}\text { il campione, il professore } \\
\text { lo fa osservare allo } \\
\text { scienziato }\end{array}$ & $\begin{array}{l}\text { il campione, lo scienziato } \\
\text { lo osserva attentamente }\end{array}$ & $\begin{array}{l}\text { il campione, lo scienziato lo } \\
\text { deve osservare } \\
\text { attentamente }\end{array}$ \\
\hline 22 & Prime & $\begin{array}{l}\text { la casa, il ragazzo la lava } \\
\text { tutti i giorni }\end{array}$ & $\begin{array}{l}\text { la casa, il ragazzo la deve } \\
\text { lavare tutti i giorni }\end{array}$ & $\begin{array}{l}\text { la casa, la mamma la fa } \\
\text { lavare al ragazzo }\end{array}$ \\
\hline 22 & Target & $\begin{array}{l}\text { I soldi, l'uomo li conta al } \\
\text { piu' presto }\end{array}$ & $\begin{array}{l}\text { i soldi, l'uomo li deve } \\
\text { contare al piu' presto }\end{array}$ & $\begin{array}{l}\text { i soldi, Aurora li fa contare } \\
\text { all'uomo }\end{array}$ \\
\hline 23 & Prime & $\begin{array}{l}\text { la lettera, il ragazzo la } \\
\text { deve imbucare prima di } \\
\text { sera }\end{array}$ & $\begin{array}{l}\text { la lettera, Alice la fa } \\
\text { imbucare dal ragazzo }\end{array}$ & $\begin{array}{l}\text { la lettera, il ragazzo la } \\
\text { imbuca prima di sera }\end{array}$ \\
\hline 23 & Target & $\begin{array}{l}\text { il tavolo, l'operaio lo deve } \\
\text { misurare con } \\
\text { attentamente }\end{array}$ & $\begin{array}{l}\text { il tavolo, Aurora lo fa } \\
\text { misurare dall'operaio }\end{array}$ & $\begin{array}{l}\text { il tavolo, l'operaio lo } \\
\text { misura attentamente }\end{array}$ \\
\hline 24 & Prime & $\begin{array}{l}\text { la coppa, Massimo la fa } \\
\text { presentare dal presidente }\end{array}$ & $\begin{array}{l}\text { la coppa, il presidente la } \\
\text { presenta all'atleta }\end{array}$ & $\begin{array}{l}\text { la coppa, il presidente la } \\
\text { deve presentare all'atleta }\end{array}$ \\
\hline 24 & Target & $\begin{array}{l}\text { l'uomo, Raniero lo fa } \\
\text { arrestare dal poliziotto }\end{array}$ & $\begin{array}{l}\text { l'uomo, il poliziotto lo } \\
\text { arresta al momento }\end{array}$ & $\begin{array}{l}\text { l'uomo, il poliziotto lo deve } \\
\text { arrestare al momento }\end{array}$ \\
\hline
\end{tabular}




\section{Filler items: Constant across each version of the task}

\begin{tabular}{|c|c|c|c|}
\hline Item & Version 1 & Version 2 & Version 3 \\
\hline 1 & $\begin{array}{l}\text { la scarpa si mette prima } \\
\text { di uscire }\end{array}$ & $\begin{array}{l}\text { la scarpa si mette prima } \\
\text { di uscire }\end{array}$ & $\begin{array}{l}\text { la scarpa si mette prima } \\
\text { di uscire }\end{array}$ \\
\hline 2 & $\begin{array}{l}\text { la nota si archivia nei } \\
\text { piccoli cassetti }\end{array}$ & $\begin{array}{l}\text { la nota si archivia nei } \\
\text { piccoli cassetti }\end{array}$ & $\begin{array}{l}\text { la nota si archivia nei } \\
\text { piccoli cassetti }\end{array}$ \\
\hline 3 & $\begin{array}{l}\text { l'acqua si apre con la } \\
\text { manovella }\end{array}$ & $\begin{array}{l}\text { l'acqua si apre con la } \\
\text { manovella }\end{array}$ & $\begin{array}{l}\text { l'acqua si apre con la } \\
\text { manovella }\end{array}$ \\
\hline 4 & $\begin{array}{l}\text { I panni si stendono con } \\
\text { le pinzette }\end{array}$ & $\begin{array}{l}\text { I panni si stendono con } \\
\text { le pinzette }\end{array}$ & $\begin{array}{l}\text { I panni si stendono con } \\
\text { le pinzette }\end{array}$ \\
\hline 5 & $\begin{array}{l}\text { l'uovo si frigge in padella } \\
\text { calda }\end{array}$ & $\begin{array}{l}\text { l'uovo si frigge in padella } \\
\text { calda }\end{array}$ & $\begin{array}{l}\text { l'uovo si frigge in padella } \\
\text { calda }\end{array}$ \\
\hline 6 & $\begin{array}{l}\text { la mela si pela con il } \\
\text { coltello }\end{array}$ & $\begin{array}{l}\text { la mela si pela con il } \\
\text { coltello }\end{array}$ & la mela si pela con il coltello \\
\hline 7 & $\begin{array}{l}\text { Il pizzicotto si tira con } \\
\text { due dita }\end{array}$ & $\begin{array}{l}\text { Il pizzicotto si tira con } \\
\text { due dita }\end{array}$ & $\begin{array}{l}\text { Il pizzicotto si tira con } \\
\text { due dita }\end{array}$ \\
\hline 8 & $\begin{array}{l}\text { la lampada si lucida a } \\
\text { mano calda }\end{array}$ & $\begin{array}{l}\text { la lampada si lucida a } \\
\text { mano calda }\end{array}$ & $\begin{array}{l}\text { la lampada si lucida a } \\
\text { mano calda }\end{array}$ \\
\hline 9 & $\begin{array}{l}\text { la mela si taglia con un } \\
\text { coltello }\end{array}$ & $\begin{array}{l}\text { la mela si taglia con un } \\
\text { coltello }\end{array}$ & $\begin{array}{l}\text { la mela si taglia con un } \\
\text { coltello }\end{array}$ \\
\hline 10 & $\begin{array}{l}\text { la vacca si munge con } \\
\text { due mani }\end{array}$ & $\begin{array}{l}\text { la vacca si munge con } \\
\text { due mani }\end{array}$ & $\begin{array}{l}\text { la vacca si munge con } \\
\text { due mani }\end{array}$ \\
\hline 11 & $\begin{array}{l}\text { I fiori si raccolgono tre } \\
\text { alla volta }\end{array}$ & $\begin{array}{l}\text { I fiori si raccolgono tre } \\
\text { alla volta }\end{array}$ & $\begin{array}{l}\text { I fiori si raccolgono tre } \\
\text { alla volta }\end{array}$ \\
\hline 12 & $\begin{array}{l}\text { il cavallo si cavalca con } \\
\text { le redini }\end{array}$ & $\begin{array}{l}\text { il cavallo si cavalca con le } \\
\text { redini }\end{array}$ & $\begin{array}{l}\text { il cavallo si cavalca con } \\
\text { le redini }\end{array}$ \\
\hline 13 & $\begin{array}{l}\text { la legna si taglia con la } \\
\text { sega }\end{array}$ & $\begin{array}{l}\text { la legna si taglia con la } \\
\text { sega }\end{array}$ & $\begin{array}{l}\text { la legna si taglia con } \\
\text { la sega }\end{array}$ \\
\hline 14 & $\begin{array}{l}\text { l'alberto si scuote con } \\
\text { le braccia }\end{array}$ & $\begin{array}{l}\text { l'alberto si scuote con } \\
\text { le braccia }\end{array}$ & $\begin{array}{l}\text { l'alberto si scuote con } \\
\text { le braccia }\end{array}$ \\
\hline 15 & $\begin{array}{l}\text { il latte si versa sempre } \\
\text { dal cartone }\end{array}$ & $\begin{array}{l}\text { il latte si versa sempre } \\
\text { dal cartone }\end{array}$ & $\begin{array}{l}\text { il latte si versa sempre } \\
\text { dal cartone }\end{array}$ \\
\hline 16 & $\begin{array}{l}\text { il pacco si carica sempre } \\
\text { dal retro }\end{array}$ & $\begin{array}{l}\text { il pacco si carica sempre } \\
\text { dal retro }\end{array}$ & $\begin{array}{l}\text { il pacco si carica sempre } \\
\text { dal retro }\end{array}$ \\
\hline 17 & $\begin{array}{l}\text { il regalo si apre dopo la } \\
\text { torta }\end{array}$ & $\begin{array}{l}\text { il regalo si apre dopo } \\
\text { la torta }\end{array}$ & il regalo si apre dopo la torta \\
\hline 18 & $\begin{array}{l}\text { il paziente si opera in } \\
\text { sala operatoria }\end{array}$ & $\begin{array}{l}\text { il paziente si opera in } \\
\text { sala operatoria }\end{array}$ & $\begin{array}{l}\text { il paziente si opera in } \\
\text { sala operatoria }\end{array}$ \\
\hline 19 & $\begin{array}{l}\text { I capelli si asciugano con } \\
\text { il fon }\end{array}$ & $\begin{array}{l}\text { I capelli si asciugano con } \\
\text { il fon }\end{array}$ & I capelli si asciugano con il fon \\
\hline 20 & $\begin{array}{l}\text { I capelli si lavano con } \\
\text { acqua tiepida }\end{array}$ & $\begin{array}{l}\text { I capelli si lavano con } \\
\text { acqua tiepida }\end{array}$ & $\begin{array}{l}\text { I capelli si lavano con acqua } \\
\text { tiepida }\end{array}$ \\
\hline 21 & $\begin{array}{l}\text { il quadro si dipinge con } \\
\text { vari colori }\end{array}$ & $\begin{array}{l}\text { il quadro si dipinge con } \\
\text { vari colori }\end{array}$ & $\begin{array}{l}\text { il quadro si dipinge con } \\
\text { vari colori }\end{array}$ \\
\hline
\end{tabular}




\section{(Continued)}

\begin{tabular}{llll}
\hline Item & Version 1 & Version 2 & Version 3 \\
\hline 22 & $\begin{array}{l}\text { il secchio si solleva a } \\
\text { due mani }\end{array}$ & $\begin{array}{l}\text { il secchio si solleva a } \\
\text { due mani }\end{array}$ & il secchio si solleva a due mani \\
\hline 23 & $\begin{array}{l}\text { la candela si accende } \\
\text { col fiammifero }\end{array}$ & $\begin{array}{l}\text { la candela si accende } \\
\text { col fiammifero }\end{array}$ & $\begin{array}{l}\text { la candela si accende } \\
\text { col fiammifero }\end{array}$ \\
\hline 24 & $\begin{array}{l}\text { la coppia si sposa davanti } \\
\text { al prete }\end{array}$ & $\begin{array}{l}\text { la coppia si sposa davanti } \\
\text { al prete }\end{array}$ & $\begin{array}{l}\text { la coppia si sposa davanti } \\
\text { al prete }\end{array}$ \\
\hline
\end{tabular}

Cite this article: Romano, F.B. (2020). Ultimate attainment in heritage language speakers: Syntactic and morphological knowledge of Italian accusative clitics. Applied Psycholinguistics 41, 347-380. https:// doi.org/10.1017/S0142716419000559 